\title{
Regular treatment with formoterol and an inhaled corticosteroid versus regular treatment with salmeterol and an inhaled corticosteroid for chronic asthma: serious adverse events (Review)
}

\section{Cates CJ, Lasserson TJ}

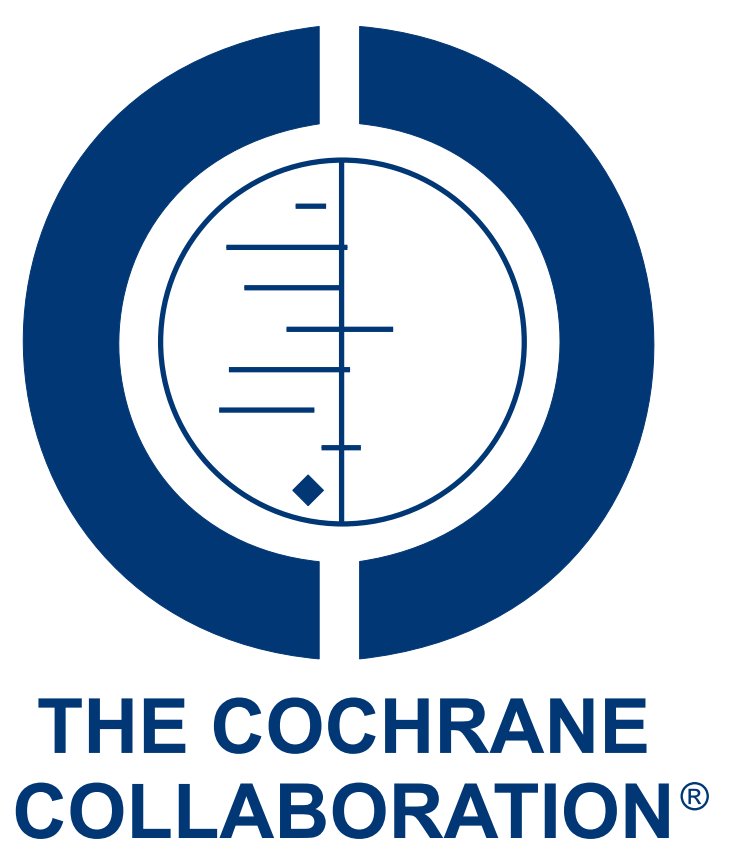

This is a reprint of a Cochrane review, prepared and maintained by The Cochrane Collaboration and published in The Cochrane Library 2011, Issue 12

http://www.thecochranelibrary.com

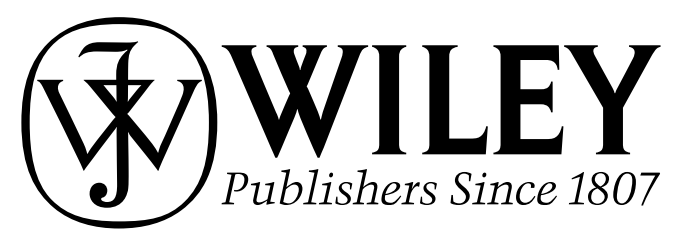

Regular treatment with formoterol and an inhaled corticosteroid versus regular treatment with salmeterol and an inhaled corticosteroid for chronic asthma: serious adverse events (Review)

Copyright ( 201 I The Cochrane Collaboration. Published by John Wiley \& Sons, Ltd. 
TABLE OF CONTENTS

HEADER . . . . . . . . . . . . . . . . . . . . . . . . . . . . . . . . . . . . . . . 1

ABSTRACT . . . . . . . . . . . . . . . . . . . . . . . . . . . . . . . . . . . . . . . . . . . . . . 1

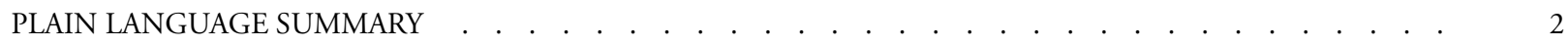

SUMMARY OF FINDINGS FOR THE MAIN COMPARISON . . . . . . . . . . . . . . . . . . . . . . . . 3

BACKGROUND . . . . . . . . . . . . . . . . . . . . . . . . . . . . . . . . . . . . . 6

OBJECTIVES . . . . . . . . . . . . . . . . . . . . . . . . . . . . . . . . . . . . . . . . . . . . . . . 6

METHODS . . . . . . . . . . . . . . . . . . . . . . . . . . . . . . . . . . . . . . 6

RESULTS . . . . . . . . . . . . . . . . . . . . . . . . . . . . . . . . . . . . . . . 8

Figure 1. . . . . . . . . . . . . . . . . . . . . . . . . . . . . . . . . . . . . . 10

Figure 2. . . . . . . . . . . . . . . . . . . . . . . . . . . . . . . . . . . . . . 12

Figure 3. . . . . . . . . . . . . . . . . . . . . . . . . . . . . . . . . . . . . . 13

Figure $4 . \quad$. . . . . . . . . . . . . . . . . . . . . . . . . . . . . . . . . . . . . 14

Figure 5. . . . . . . . . . . . . . . . . . . . . . . . . . . . . . . . . . . 15

DISCUSSION . . . . . . . . . . . . . . . . . . . . . . . . . . . . . . . . . . . . . 16

AUTHORS' CONCLUSIONS . . . . . . . . . . . . . . . . . . . . . . . . . . . . . . . . 16

ACKNOWLEDGEMENTS . . . . . . . . . . . . . . . . . . . . . . . . . . . . . . . . . . . 17

REFERENCES . . . . . . . . . . . . . . . . . . . . . . . . . . . . . . . . . . . . . 17

CHARACTERISTICS OF STUDIES . . . . . . . . . . . . . . . . . . . . . . . . . . . . . . . . . 21

DATA AND ANALYSES . . . . . . . . . . . . . . . . . . . . . . . . . . . . . . . . . . . . . . . . . . . . . . . . 38

Analysis 1.1. Comparison 1 Fixed-dose formoterol/ICS versus salmeterol/fluticasone, Outcome 1 All-cause mortality. 39

Analysis 1.2. Comparison 1 Fixed-dose formoterol/ICS versus salmeterol/fluticasone, Outcome 2 All-cause non-fatal serious adverse events. . . . . . . . . . . . . . . . . . . . . . . . . . . . . . . . 41

Analysis 1.3. Comparison 1 Fixed-dose formoterol/ICS versus salmeterol/fluticasone, Outcome 3 Asthma related non-fatal serious adverse events. . . . . . . . . . . . . . . . . . . . . . . . . . . . . . . . 42

Analysis 1.4. Comparison 1 Fixed-dose formoterol/ICS versus salmeterol/fluticasone, Outcome 4 All-cause mortality (risk difference).

Analysis 1.5. Comparison 1 Fixed-dose formoterol/ICS versus salmeterol/fluticasone, Outcome 5 All-cause non-fatal

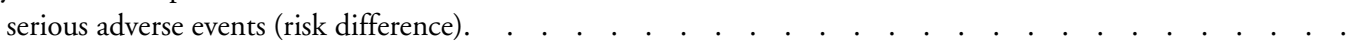

Analysis 1.6. Comparison 1 Fixed-dose formoterol/ICS versus salmeterol/fluticasone, Outcome 6 Asthma-related non-fatal serious adverse events (risk difference). . . . . . . . . . . . . . . . . . . . . . . . . . 45

ADDITIONAL TABLES . . . . . . . . . . . . . . . . . . . . . . . . . . . . . . . . . . . . . . 46

APPENDICES . . . . . . . . . . . . . . . . . . . . . . . . . . . . . . . . . . . . . 47

WHAT'S NEW .. . . . . . . . . . . . . . . . . . . . . . . . . . . . . . . . . . . . . 49

HISTORY . . . . . . . . . . . . . . . . . . . . . . . . . . . . . . . . . . . . . . . 49

CONTRIBUTIONS OF AUTHORS . . . . . . . . . . . . . . . . . . . . . . . . . . . . . . . . . . . 50

DECLARATIONS OF INTEREST . . . . . . . . . . . . . . . . . . . . . . . . . . . . . . . . 50

SOURCES OF SUPPORT . . . . . . . . . . . . . . . . . . . . . . . . . . . . . . . . . . . . . . . . . 50

DIFFERENCES BETWEEN PROTOCOL AND REVIEW . . . . . . . . . . . . . . . . . . . . . . 50

INDEX TERMS . . . . . . . . . . . . . . . . . . . . . . . . . . . . . . . . . . . . 50

Regular treatment with formoterol and an inhaled corticosteroid versus regular treatment with salmeterol and an inhaled corticosteroid i for chronic asthma: serious adverse events (Review)

Copyright $\odot 2011$ The Cochrane Collaboration. Published by John Wiley \& Sons, Ltd. 


\title{
Regular treatment with formoterol and an inhaled corticosteroid versus regular treatment with salmeterol and an inhaled corticosteroid for chronic asthma: serious adverse events
}

\author{
Christopher J Cates ${ }^{1}$, Toby J Lasserson ${ }^{2}$ \\ ${ }^{1}$ Population Health Sciences and Education, St George's, University of London, London, UK. ${ }^{2}$ Cochrane Editorial Unit, The Cochrane \\ Collaboration, London, UK \\ Contact address: Christopher J Cates, Population Health Sciences and Education, St George's, University of London, Cranmer Terrace, \\ London, SW17 0RE, UK. ccates@sgul.ac.uk. \\ Editorial group: Cochrane Airways Group. \\ Publication status and date: New search for studies and content updated (no change to conclusions), published in Issue 12, 2011. \\ Review content assessed as up-to-date: 17 August 2011. \\ Citation: Cates CJ, Lasserson TJ. Regular treatment with formoterol and an inhaled corticosteroid versus regular treatment with \\ salmeterol and an inhaled corticosteroid for chronic asthma: serious adverse events. Cochrane Database of Systematic Reviews 2010, Issue \\ 1. Art. No.: CD007694. DOI: 10.1002/14651858.CD007694.pub2.
}

Copyright (C 2011 The Cochrane Collaboration. Published by John Wiley \& Sons, Ltd.

\begin{abstract}
A B S T R A C T
Background

An increase in serious adverse events with the use of both regular formoterol and regular salmeterol (long-acting beta 2 -agonists) in chronic asthma has been demonstrated in comparison with placebo in previous Cochrane reviews. This increase was significant in trials that did not randomise participants to an inhaled corticosteroid. However, systematic reviews of trials in which each drug was randomised with an inhaled corticosteroid did not demonstrate significant increases in serious adverse events. The confidence intervals were found to be too wide to be sure that the addition of an inhaled corticosteroid renders regular long-acting beta 2 -agonists completely safe; there were fewer participants and insufficient serious adverse events in these trials to come to a definitive decision about the safety of combination treatments.
\end{abstract}

Objectives

We set out to compare the risks of mortality and non-fatal serious adverse events in trials which have randomised patients with chronic asthma to regular formoterol versus regular salmeterol, when each are used with an inhaled corticosteroid as part of the randomised treatment.

\section{Search methods}

We identified trials using the Cochrane Airways Group Specialised Register of trials. We checked manufacturers' websites of clinical trial registers for unpublished trial data and also checked Food and Drug Administration (FDA) submissions in relation to formoterol and salmeterol. The date of the most recent search was August 2011.

\section{Selection criteria}

We included controlled clinical trials with a parallel design, recruiting patients of any age and severity of asthma, if they randomised patients to treatment with regular formoterol versus regular salmeterol (each with a randomised inhaled corticosteroid) and were of at least 12 weeks duration.

Regular treatment with formoterol and an inhaled corticosteroid versus regular treatment with salmeterol and an inhaled corticosteroid $\mathbf{I}$ for chronic asthma: serious adverse events (Review)

Copyright @ 2011 The Cochrane Collaboration. Published by John Wiley \& Sons, Ltd. 


\section{Data collection and analysis}

Two review authors independently selected trials for inclusion in the review and extracted outcome data. We sought unpublished data on mortality and serious adverse events from the sponsors and authors.

\section{Main results}

Ten studies on 6769 adults and adolescents met the eligibility criteria of the review. Seven studies (involving 5935 adults and adolescents) compared formoterol and budesonide to salmeterol and fluticasone. All but one study administered the products as a combined inhaler, and most used formoterol $12 \mu \mathrm{g}$ and budesonide $400 \mu \mathrm{g}$ twice daily versus salmeterol $50 \mu \mathrm{g}$ and fluticasone $250 \mu \mathrm{g}$ twice daily. There were two deaths overall (one on each combination) and neither were thought to be related to asthma.

There was no significant difference between treatment groups (formoterol/budesonide versus salmeterol/fluticasone) for non-fatal serious adverse events, either all-cause (Peto odds ratio (OR) 1.14; 95\% confidence interval (CI) 0.82 to 1.59 , $\mathrm{I}^{2}=26 \%$ ) or asthmarelated (Peto OR 0.69; 95\% CI 0.37 to $1.26, \mathrm{I}^{2}=33 \%$ ). Over 23 weeks the rates for all-cause serious adverse events were $2.6 \%$ on formoterol and budesonide and $2.3 \%$ on salmeterol and fluticasone, and for asthma-related serious adverse events, $0.6 \%$ and $0.8 \%$ respectively.

There was one study (228 adults) comparing formoterol and beclomethasone to salmeterol and fluticasone, but there were no deaths or hospital admissions. One study (404 adults) compared formoterol and mometasone to salmeterol and fluticasone for 52 weeks, but the small number of events leaves considerable uncertainty about the comparative safety of the two products. Similarly one study (202 adults) compared formoterol and fluticasone with salmeterol and fluticasone, but there was only one serious adverse event in each group.

No studies were found in children.

\section{Authors' conclusions}

The seven identified studies in adults did not show any significant difference in safety between formoterol and budesonide in comparison with salmeterol and fluticasone. Asthma-related serious adverse events were rare, and there were no reported asthma-related deaths. There was a single, small study comparing formoterol and beclomethasone to salmeterol and fluticasone in adults, a single study comparing formoterol and mometasone with salmeterol and fluticasone in adults, and a single study comparing formoterol and fluticasone with salmeterol and fluticasone in adults.

No studies were found in children, so no conclusion can be drawn for this age group.

Overall there is insufficient evidence to decide whether regular formoterol in combination with budesonide, beclometasone, fluticasone or mometasone have equivalent or different safety profiles from salmeterol in combination with fluticasone.

\section{PLAIN LANGUAGE SUMMARY}

Do people with asthma have fewer serious adverse events when taking formoterol and inhaled corticosteroids or salmeterol and inhaled corticosteroids?

Asthma is a condition that affects the airways - the small tubes that carry air in and out of the lungs. When a person with asthma comes into contact with an asthma trigger, their airways become irritated and the muscles around the walls of the airways tighten so that the airways become narrower (bronchoconstriction) and the lining of the airways becomes inflamed and starts to swell. Sometimes, sticky mucus or phlegm builds up, which can further narrow the airways. These reactions cause the airways to become narrower and irritated - making it difficult to breathe and leading to coughing, wheezing, shortness of breath and tightness in the chest. People with asthma are generally advised to take inhaled steroids to combat the underlying inflammation, but if asthma is still not controlled, current clinical guidelines for people with asthma recommend the introduction of an additional medication to help. A common strategy in these situations is to use a long-acting beta-agonists: formoterol or salmeterol. A long-acting beta-agonist is an inhaled drug which opens the airways (bronchodilator) making it easier to breath.

We know from previous Cochrane reviews that there is a small increase in serious adverse events (such as very severe asthma attacks as well as other life-threatening events) when either of regular formoterol and regular salmeterol are compared with placebo treatment in patients who are not also taking inhaled steroids. This review sought information from trials that compared the two treatments (i.e.

Regular treatment with formoterol and an inhaled corticosteroid versus regular treatment with salmeterol and an inhaled corticosteroid 2 for chronic asthma: serious adverse events (Review) 
when people taking salmeterol with an inhaled corticosteroid were compared directly with people taking formoterol and an inhaled corticosteroid) to see if we could determine which drug was the safest.

We found 10 trials on 6769 adults and adolescents, but we did not find any trials on children. We found no significant difference between the treatments, but serious adverse events were too rare to be confident that the risks are the same for both treatments. There are no trials in children; we therefore could not draw any conclusions for children and so more trials are needed. 


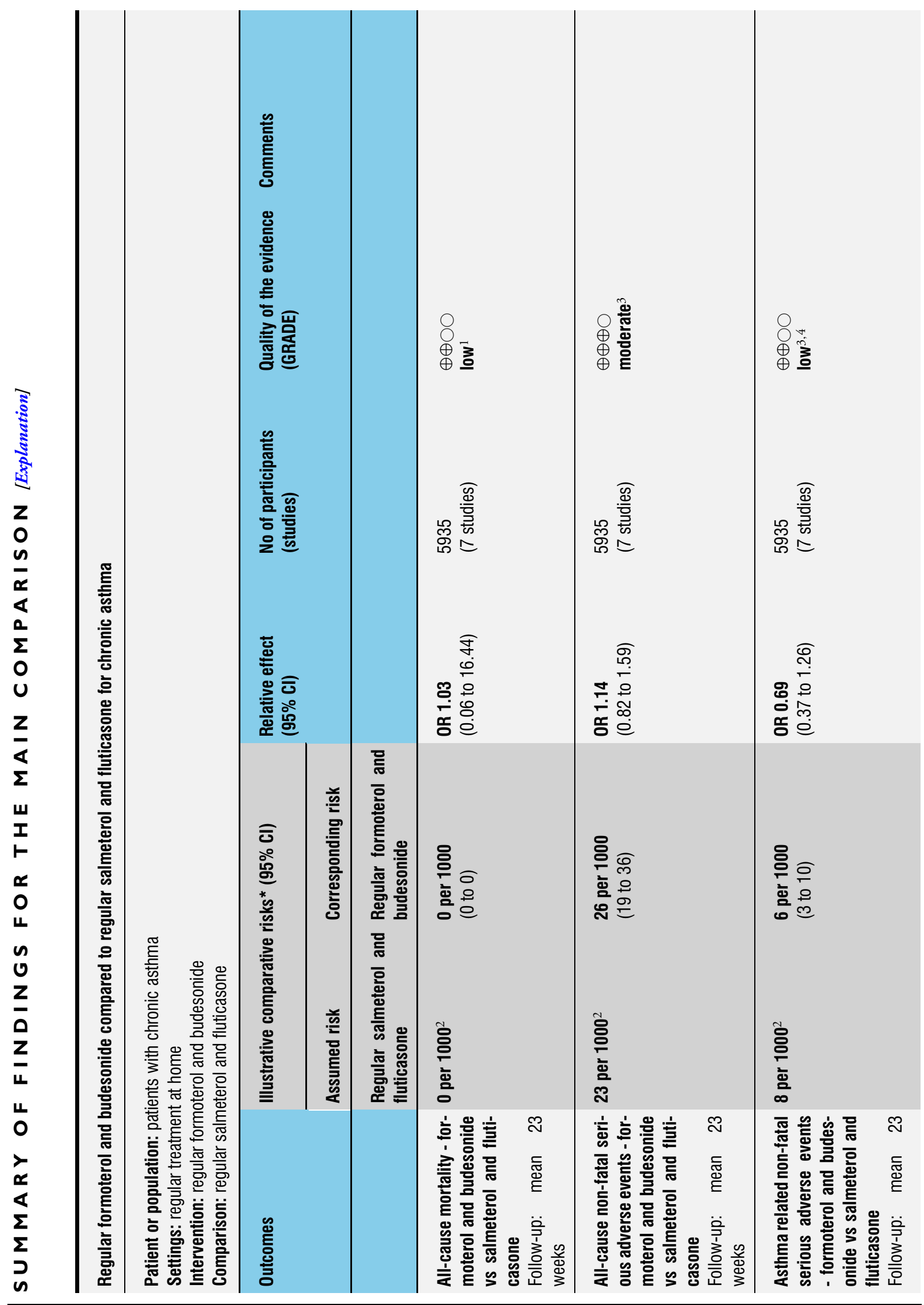

Regular treatment with formoterol and an inhaled corticosteroid versus regular treatment with salmeterol and an inhaled corticosteroid 4 for chronic asthma: serious adverse events (Review)

Copyright (? 201 I The Cochrane Collaboration. Published by John Wiley \& Sons, Ltd. 


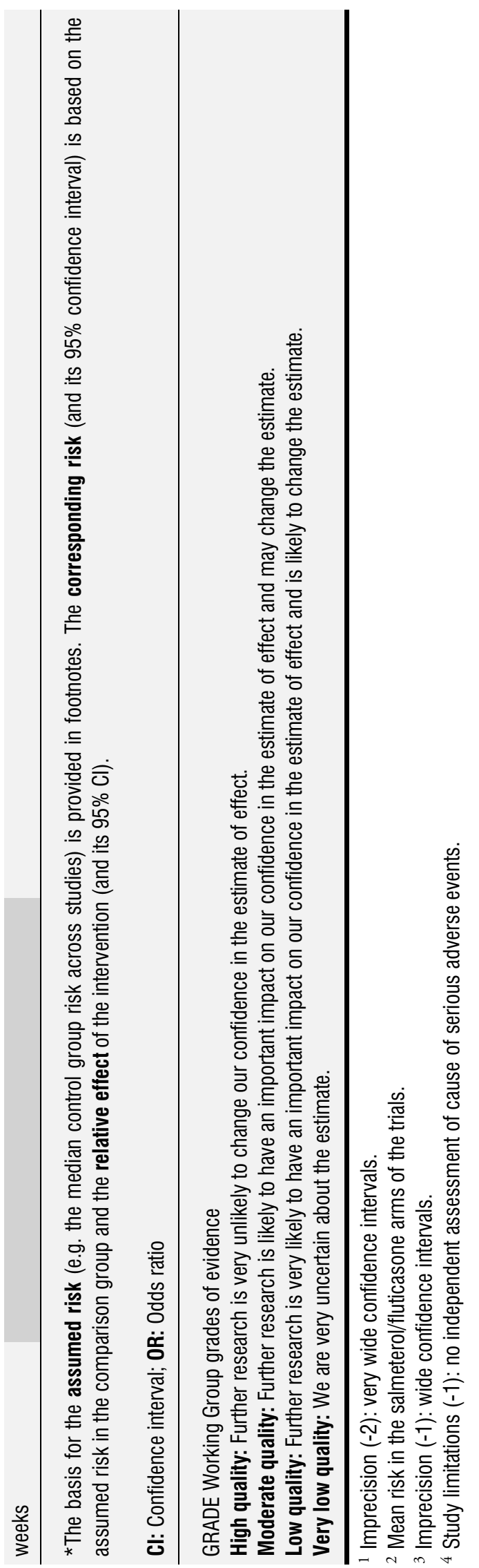

Regular treatment with formoterol and an inhaled corticosteroid versus regular treatment with salmeterol and an inhaled corticosteroid for chronic asthma: serious adverse events (Review)

Copyright (C) 201 I The Cochrane Collaboration. Published by John Wiley \& Sons, Ltd. 


\section{B A C K G R O U N D}

When patients with asthma are not controlled by low-dose inhaled corticosteroids alone, many asthma guidelines recommend additional long-acting beta 2 -agonists. Several Cochrane reviews have addressed the efficacy of long-acting beta2-agonists given with inhaled corticosteroids (Ni Chroinin 2009; Ni Chroinin 2010), in comparison with placebo (Walters 2007), short-acting beta 2 -agonists (Walters 2002), leukotriene-receptor antagonists (Ducharme 2011) and increased doses of inhaled corticosteroids (Ducharme 2010). The beneficial effects of long-acting beta 2 -agonists on lung function, symptoms, quality of life and exacerbations requiring oral steroids have been demonstrated, and a rationale has been put forward for their use in combination with an inhaled corticosteroid (Barnes 2002).

Concern remains that regular treatment with long-acting beta 2 agonists might lead to an increase in asthma-related deaths (as seen in SMART 2006). Regular treatment with beta2-agonists can lead to tolerance to their bronchodilator effects with both long-acting and short-acting compounds (Lipworth 1997). A number of molecular mechanisms have been proposed to explain the possible detrimental effect of long-term beta 2 -agonist use in asthma, including receptor down-regulation and desensitisation (Giembycz 2006).

A recent meta-analysis of the effect of long-acting beta 2 -agonists on severe asthma exacerbations and asthma-related deaths (Salpeter 2006) concluded that "long-acting beta-agonists have been shown to increase severe and life-threatening asthma exacerbations, as well as asthma-related deaths". Salpeter 2006 considered trials that compared any long-acting beta 2 -agonists with placebo, and the review was not able to include 28 trials in the primary analysis (including nearly 6000 patients) because information was not provided for asthma-related deaths.

Currently there are two long-acting beta 2 -agonists available, salmeterol and formoterol (also known as eformoterol). These two drugs are known to have differences in speed of onset and receptor activity, and are used in different ways (for example, salmeterol has a slower onset of action than salbutamol, Beach 1992). For this reason we have considered salmeterol and formoterol separately in our previous work.

Two of our published reviews have assessed the risk of fatal and non-fatal serious adverse events with regular salmeterol (Cates 2008) and formoterol (Cates 2008a) in comparison to placebo or short-acting beta2-agonists. In comparison to placebo, adults on regular salmeterol and children on regular formoterol demonstrated a significant increase in all-cause non-fatal serious adverse events. Two further reviews, in which each drug was randomised with an inhaled corticosteroid in comparison to the same dose of the inhaled corticosteroid have also been completed (Cates 2009; Cates 2009a). These did not demonstrate significant increases in serious adverse events, but the confidence intervals are too wide to be sure that the addition of an inhaled corticosteroid renders regular long-acting beta 2 -agonists completely safe. Moreover, indirect comparisons on the relative safety of formoterol and salmeterol from the results of these existing reviews are subject to confounding due to differences in the participants, interventions, comparisons and outcomes in the trials of each review.

A review comparing the safety of regular formoterol and salmeterol without a randomised inhaled corticosteroid has also been carried out from trials that have made head-to-head comparisons of the two products (Cates 2009b). The trials that were included in Cates 2009b turned out to have used background inhaled corticosteroids in all participants. However, no previous review has compared regular formoterol to regular salmeterol from trials in which an inhaled corticosteroid was a mandatory part of the randomised treatment. We have considered this to be a separate question, as adherence with an inhaled corticosteroid may be better when it is part of the randomised treatment schedule (particularly if a combined inhaler is used).

This review, therefore, sets out to compare the safety of regular formoterol and regular salmeterol when each is used in combination with a randomised inhaled corticosteroid.

\section{O B J E C T IVES}

To assess the risk of mortality and non-fatal serious adverse events in trials which have randomised patients with chronic asthma to regular formoterol and an inhaled corticosteroid versus regular salmeterol and an inhaled corticosteroid.

\section{METHODS}

\section{Criteria for considering studies for this review}

\section{Types of studies}

We included controlled, parallel-design clinical trials, with or without blinding, in which patients with chronic asthma were randomly assigned to regular treatment with formoterol and an inhaled corticosteroid versus salmeterol and an inhaled corticosteroid. We excluded studies on acute asthma and exercise-induced bronchospasm.

\section{Types of participants}

We included patients with a clinical diagnosis of asthma of any age group, unrestricted by disease severity, previous or current treatment.

Regular treatment with formoterol and an inhaled corticosteroid versus regular treatment with salmeterol and an inhaled corticosteroid 6 for chronic asthma: serious adverse events (Review) 


\section{Types of interventions}

We included trials randomising patients to formoterol versus salmeterol given regularly in combination with an inhaled corticosteroid at any dose and delivered at fixed dose by any single or separate devices (chlorofluorocarbon metered dose inhaler (CFCMDI); hydrofluoroalkane metered dose inhaler (HFA-MDI); dry powder inhaler (DPI)) for a period of at least 12 weeks. We excluded studies that used adjustable maintenance dosing and single inhaler therapy (for maintenance and relief of symptoms).

\section{Types of outcome measures}

\section{Primary outcomes}

1. All-cause mortality

2. All-cause non-fatal serious adverse events (see definition below)

\section{Secondary outcomes}

1. Asthma-related mortality

2. Asthma-related non-fatal serious adverse events

3. Cardiovascular-related mortality

We did not subdivide outcomes according to whether the trial investigators considered them to be related to trial medication. We accepted trial investigators' judgement of whether serious adverse events were asthma-related or not.

An assessment of efficacy outcomes (such as exacerbations, symptoms and lung function) of these drug combinations when codelivered via the same inhaler has been undertaken and published elsewhere (Lasserson 2008).

\section{Definition of serious adverse events}

The Expert Working Group (Efficacy) of the International Conference on Harmonisation of Technical Requirements for Registration of Pharmaceuticals for Human Use (ICH) define serious adverse events as follows (ICHE2a 1995):

"A serious adverse event (experience) or reaction is any untoward medical occurrence that at any dose:

- results in death,

- is life-threatening,

- requires inpatient hospitalization or prolongation of existing hospitalization,

- results in persistent or significant disability/incapacity, or

- is a congenital anomaly/birth defect.

NOTE: The term "life-threatening" in the definition of "serious" refers to an event in which the patient was at risk of death at the time of the event; it does not refer to an event which hypothetically might have caused death if it were more severe."

\section{Search methods for identification of studies}

\section{Electronic searches}

We identified trials using the Cochrane Airways Group Specialised Register of trials, which is derived from systematic searches of bibliographic databases including the Cochrane Central Register of Controlled Trials (CENTRAL), MEDLINE, EMBASE, CINAHL, AMED and PsycINFO, and handsearching of respiratory journals and meeting abstracts (please see Appendix 1). We searched all records in the Specialised Register coded as 'asthma' using the following terms:

(((salmeterol or serevent) AND (formoterol or eformoterol or oxis or foradil) AND (steroid* or corticosteroid* or ICS or fluticasone or FP or Flixotide or budesonide or BUD or Pulmicort or beclomethasone or becotide or becloforte or becodisk or QVAR or ciclesonide or triamcinolone or flunisolide or mometasone)) OR (Symbicort or Viani or Seretide or Advair or Inuvair)) AND (serious or safety or surveillance or mortality or death or intubat* or adverse or toxicity or complications or tolerability)

In addition we carried out a second search just using the terms: (salmeterol or serevent) AND (formoterol or eformoterol or oxis or foradil).

The date of the most recent search was August 2011.

\section{Searching other resources}

We checked reference lists of all primary studies and review articles for additional references. We checked websites of clinical trial registers for unpublished trial data and we also checked FDA submissions in relation to salmeterol and formoterol.

\section{Data collection and analysis}

\section{Selection of studies}

One review author (CJC) independently assessed studies identified in the literature searches by examining titles, abstracts and keyword fields. We obtained studies that potentially fulfilled the inclusion criteria in full text. Two review authors (CJC and TL) independently assessed full-text articles for inclusion. No disagreements occurred.

\section{Data extraction and management}

One review author (CJC) extracted data using a prepared checklist and entered data into RevMan 5. The second review author (TL) independently checked the data extraction and entry. We extracted data on characteristics of included studies (methods, participants, interventions, outcomes) and results of the included studies. We contacted authors and sponsors of included studies for unpublished adverse event data and searched manufacturers' websites for

Regular treatment with formoterol and an inhaled corticosteroid versus regular treatment with salmeterol and an inhaled corticosteroid 7 for chronic asthma: serious adverse events (Review) 
further details of adverse events. We also searched FDA submissions. We recorded all-cause serious adverse events (fatal and nonfatal) and in view of the difficulty in deciding whether events are asthma-related, noted details of the cause of death and serious adverse events. We requested further information when causation was not clear (particularly in relation to hospital admissions and serious adverse events).

\section{Assessment of risk of bias in included studies}

One review author (CJC) assessed the included studies for bias protection (including sequence generation for randomisation, allocation concealment, blinding of participants and assessors, loss to follow-up, completeness of outcome assessment and other possible bias prevention). We judged risk of bias as either high, low or unclear according to recommendations in the Cochrane Handbook of Systematic Reviews of Interventions (Higgins 2008).

\section{Unit of analysis issues}

We confined our analysis to patients with one or more serious adverse events, rather than the number of events that occurred (as the latter are not independent when one patient suffers multiple events).

\section{Assessment of heterogeneity}

We assessed heterogeneity using the $\mathrm{I}^{2}$ statistic to indicate how much of the total heterogeneity found was between, rather than within studies.

\section{Assessment of reporting biases}

We planned to inspect funnel plots to assess publication bias.

\section{Data synthesis}

The outcomes of this review were dichotomous and we recorded the number of participants with one or more of each outcome event, by allocated treated group. We calculated pooled odds ratios $(\mathrm{OR})$ and risk differences $(\mathrm{RD})$. The Peto odds ratio has advantages when events are rare, as no adjustment for zero cells is required. This property was found in previous reviews to be more important than potential problems with unbalanced treatment arms, and we therefore calculated the results for serious adverse events in RevMan 5 using the Peto method with Mantel-Haenszel methods for sensitivity analysis.

\section{Subgroup analysis and investigation of heterogeneity}

We planned subgroup analyses on the basis of age (adults versus children) and dose of inhaled corticosteroids (equivalence between arms or not). We planned to compare subgroups using tests for interaction (Altman 2003).

\section{Sensitivity analysis}

We carried out sensitivity analysis to assess the impact of the method used to combine the study events (risk difference, Peto odds ratio and Mantel-Haenszel odds ratio). We conducted a sensitivity analysis on the degree of bias protection in the study designs.

\section{RE S U L T S}

\section{Description of studies}

See: Characteristics of included studies; Characteristics of excluded studies.

\section{Results of the search}

We carried out the original search for relevant studies in January 2009 and identified 106 potentially relevant abstracts. We obtained 12 abstracts as full articles and included seven abstracts relating to six studies (Aalbers 2004; Busse 2008; Dahl 2006; Kuna 2007; Papi 2007; Ringdal 2002). We excluded three review articles (Bleecker 2008; Dhillon 2006; Lyseng-Williamson 2003) with reasons provided in Characteristics of excluded studies. We also carried out an extended search in which the adverse event terms were excluded, and this identified a further 184 abstracts; from these we obtained 17 further full-text articles. We included two further studies from the GSK trials register (SAM 40010; SAM 40048); excluded one study (Lee 2003) and the other articles were all additional references to studies that had already been included. A total of eight studies reported in 35 separate references met the eligibility criteria of the review.

A subsequent search in July 2009 did not identify any further studies for inclusion, but there were two further potentially relevant studies that we subsequently excluded (Hampel 2008; Jung 2008), see Characteristics of excluded studies for further details. In August 2011 a further search identified three new citations for studies already included (Aalbers 2004; Busse 2008; Kuna 2007), three citations for a new study comparing formoterol and fluticasone with salmeterol and fluticasone (Bodzenta-Lukaszyk 2011) and six citations for a new study on 404 adults comparing formoterol and mometasone with salmeterol and fluticasone (Maspero 2010).

\section{Included studies}

\section{Dose and delivery of medication}

Overall in seven studies 5935 adults were randomised to formoterol and budesonide versus salmeterol and fluticasone; 228

Regular treatment with formoterol and an inhaled corticosteroid versus regular treatment with salmeterol and an inhaled corticosteroid 8 for chronic asthma: serious adverse events (Review) 
adults were randomised to formoterol and extra-fine beclomethasone versus salmeterol and fluticasone in Papi 2007, 202 adults were randomised to formoterol and fluticasone or salmeterol and fluticasone in Bodzenta-Lukaszyk 2011 and 404 adults were randomised to formoterol and mometasone or salmeterol and fluticasone in Maspero 2010.

Details of the delivery devices and doses of the medication in each trial are given in Table 1 . All the studies used combination inhalers except for Ringdal 2002, in which formoterol and budesonide were administered in separate inhalers. We judged the dose of inhaled corticosteroid in each arm to be equivalent except in Ringdal 2002 (higher-dose budesonide) and SAM 40048 (higherdose fluticasone), see Table 1 . Whilst most studies compared 12 $\mu \mathrm{g}$ formoterol twice daily with $50 \mu \mathrm{g}$ salmeterol twice daily, SAM 40010 and SAM 40048 compared $6 \mu \mathrm{g}$ formoterol with $50 \mu \mathrm{g}$ salmeterol twice daily.

\section{Run-in period}

In all studies except Busse 2008 and Bodzenta-Lukaszyk 2011, the participants continued their previous treatment with inhaled corticosteroids alone during the run-in period (those previously on long-acting beta 2 -agonist (LABA) were either excluded or discontinued LABA treatment), and were enrolled in the study if they were symptomatic at the end of run-in. Busse 2008 allowed in- haled corticosteroids (ICS) and LABA/ICS to be continued during run-in, but participants still had to be symptomatic to be enrolled into the study. Bodzenta-Lukaszyk 2011 did not specify treatment details for the screening phase of 4 to 10 days to evaluate eligibility, and Maspero 2010 kept participants on their previous medication during screening.

\section{Age of participants}

No studies were found in children. The lower age limit in the studies varied from 12 years old (Aalbers 2004; Busse 2008; Kuna 2007; Maspero 2010; SAM 40010; SAM 40048) to 16 or 18 years (Bodzenta-Lukaszyk 2011; Dahl 2006; Papi 2007; Ringdal 2002).

\section{Sponsorship and location}

All the included studies were sponsored by one of the manufacturers of combined inhalers, and the duration and location of studies are shown in Table 2.

\section{Risk of bias in included studies}

Figure 1 shows an overview of the potential risks of bias in each study 
Figure I. Methodological quality summary: review authors' judgements about each methodological quality item for each included study.

\begin{tabular}{|c|c|c|c|c|c|c|c|}
\hline & 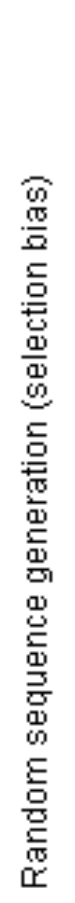 & 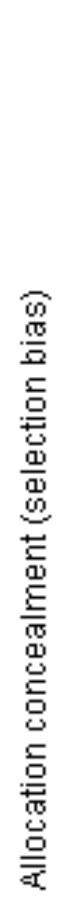 & 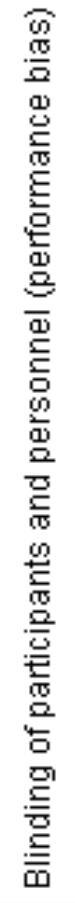 & 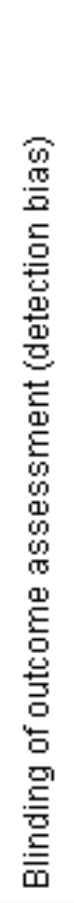 & 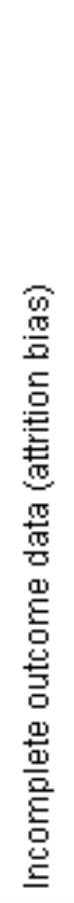 & 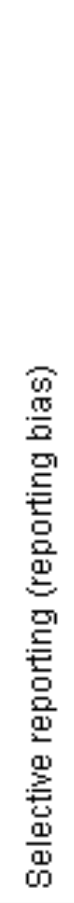 & 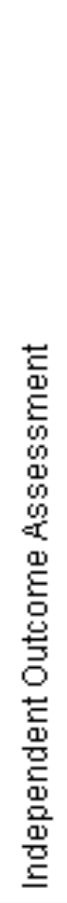 \\
\hline Aalbers 2004 & + & + & - & $?$ & $?$ & $\oplus$ & \\
\hline Bodzenta-Lukaszyk 2011 & $\oplus$ & + & - & $?$ & 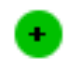 & + & \\
\hline Busse 2008 & $\oplus$ & + & - & $?$ & + & + & \\
\hline Dahl 2006 & + & + & $\oplus$ & + & $\oplus$ & $\oplus$ & \\
\hline Kuna 2007 & + & + & + & + & + & $\oplus$ & \\
\hline Maspero 2010 & $?$ & $?$ & - & + & $\oplus$ & $?$ & \\
\hline Papi 2007 & $\oplus$ & + & + & + & $\oplus$ & $\oplus$ & \\
\hline Ringdal 2002 & + & + & + & + & $\oplus$ & + & \\
\hline SAM 40010 & + & + & 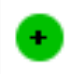 & + & $\oplus$ & + & \\
\hline SAM 40048 & + & + & + & + & $\oplus$ & $\oplus$ & \\
\hline
\end{tabular}

Regular treatment with formoterol and an inhaled corticosteroid versus regular treatment with salmeterol and an inhaled corticosteroid $\quad \mathbf{0}$ for chronic asthma: serious adverse events (Review)

Copyright ( 201 I The Cochrane Collaboration. Published by John Wiley \& Sons, Ltd. 


\section{Allocation}

We judged sequence generation and allocation concealment to be adequate in six studies (Aalbers 2004; Bodzenta-Lukaszyk 2011; Dahl 2006; Kuna 2007; Papi 2007; Ringdal 2002). The methods used were not clearly reported in four studies (Busse 2008; Maspero 2010; SAM 40010; SAM 40048).

\section{Blinding}

Four studies had well-reported methods of blinding (Dahl 2006; Kuna 2007; Ringdal 2002; SAM 40010) and four studies were open label (Aalbers 2004; Bodzenta-Lukaszyk 2011; Busse 2008; Maspero 2010) but one of these (Maspero 2010) reported that there was evaluator blinding. SAM 40048 was unclear and Papi 2007 did not use a double-dummy design but encased the inhalers in a non-removable covering.

\section{Incomplete outcome data}

All studies, with the exception of Aalbers 2004, reported that at least $80 \%$ of participants completed the study and in most cases the completion rate was $90 \%$ or above (see Characteristics of included studies for details of individual studies).

\section{Selective reporting}

Full data on serious adverse events have been obtained from all studies.

\section{Other potential sources of bias}

All the studies have been sponsored by manufacturers of combined long-acting beta 2 -agonist and inhaled corticosteroid inhalers. None of the studies had independent assessment of the cause of serious adverse events, which may present risk of bias when considering asthma-related events (rather than all-cause events).

\section{Effects of interventions}

See: Summary of findings for the main comparison Regular formoterol and budesonide compared to regular salmeterol and fluticasone for chronic asthma

\section{Formoterol/budesonide versus salmeterol/fluticasone}

\section{Mortality}

Two deaths were reported in 5935 adult and adolescent participants and neither was asthma-related. In SAM 40010 there was one death in formoterol/budesonide group due to gastrointestinal obstruction, cardiac failure and septic shock. In Kuna 2007 there was one death in the salmeterol/fluticasone group due to cardiac failure. The pooled results do not show a significant difference in all-cause mortality using Peto odds ratio (Peto OR 1.03; 95\% confidence interval (CI) 0.06 to $16.44, \mathrm{I}^{2}=50 \%$ ) (see Figure 2), or risk difference (RD $0.000009 ; 95 \%$ CI -0.002 to $0.002, \mathrm{I}^{2}=$ $0 \%)$ 
Figure 2. Forest plot of comparison: I Fixed-dose formoterol/ICS versus salmeterol/fluticasone, outcome: I.I All-cause mortality.

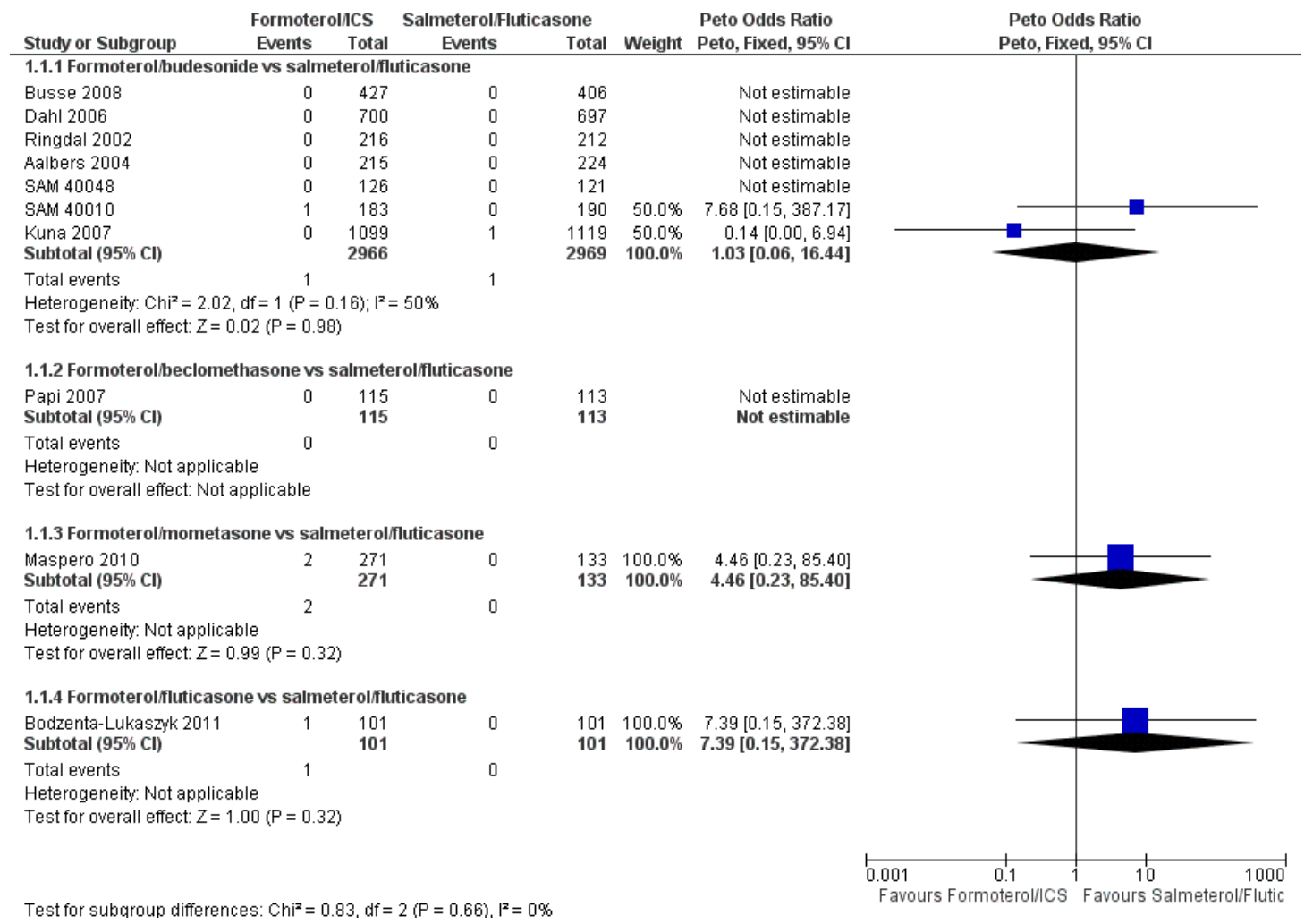

There is insufficient information to consider asthma-related or cardiovascular-related mortality (which were secondary outcomes in our protocol).

\section{All-cause non-fatal serious adverse events}

There were 77 out of 2966 adults and adolescents on formoterol and budesonide who suffered one or more serious adverse events, compared to 68 out of 2969 patients on salmeterol and fluticasone. This is not a significant difference when combined as an odds ratio (Peto OR 1.14; 95\% CI 0.82 to $1.59, \mathrm{I}^{2}=26 \%$ ) (see Figure 3), or as a risk difference (RD 0.003; 95\% CI -0.005 to $0.011, \mathrm{I}^{2}=$ $21 \%)$. 
Figure 3. Forest plot of comparison: I Fixed-dose formoterol/ICS versus salmeterol/fluticasone, outcome: I.2 All-cause non-fatal serious adverse events.

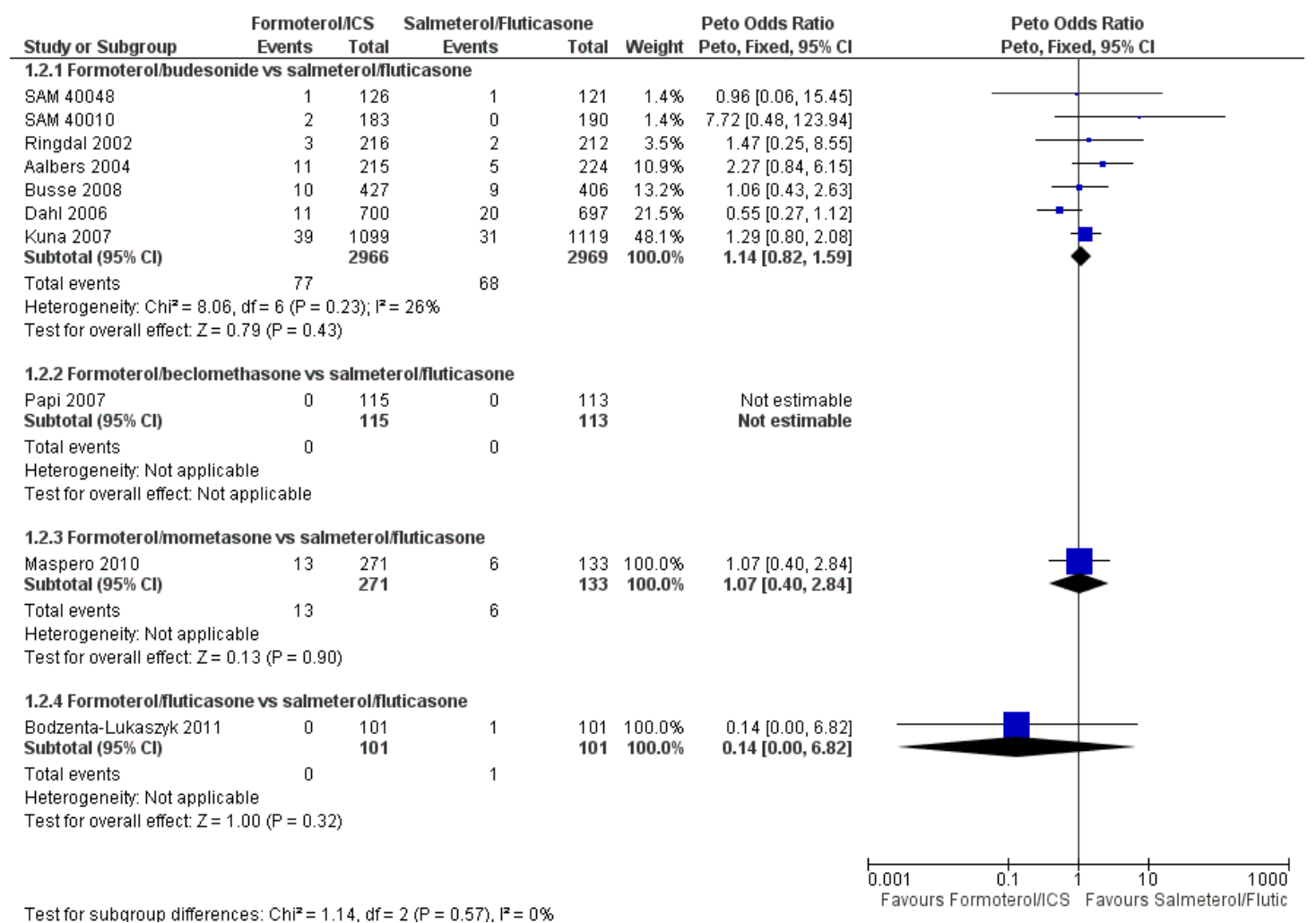

Busse 2008 reported nine participants who suffered a serious adverse event in each arm of the trial (table $S 4$ of the paper), but one additional participant on formoterol/budesonide was admitted to hospital on treatment for an episode that was judged to have started during run-in. Another participant had a serious adverse event after the last dose of randomised treatment, but correspondence with the sponsors indicated that this participant had already suffered a serious adverse event on treatment, and so was already included. We therefore decided to enter 10 participants for the formoterol/budesonide arm of this trial. We carried out sensitivity analysis to assess the impact of excluding the additional patient in the formoterol/budesonide arm and the results showed very little difference in the odds ratio (Peto OR 1.13; 95\% CI 0.81 to 1.57 , $\left.\mathrm{I}^{2}=27 \%\right)$ as shown in Figure 4.

Regular treatment with formoterol and an inhaled corticosteroid versus regular treatment with salmeterol and an inhaled corticosteroid 13 for chronic asthma: serious adverse events (Review) 
Figure 4. Forest plot of comparison: I Fixed-dose formoterol/ICS versus salmeterol/fluticasone, outcome: I.2 All-cause non-fatal serious adverse events (without the additional participant on formoterol/budesonide in Busse 2008).

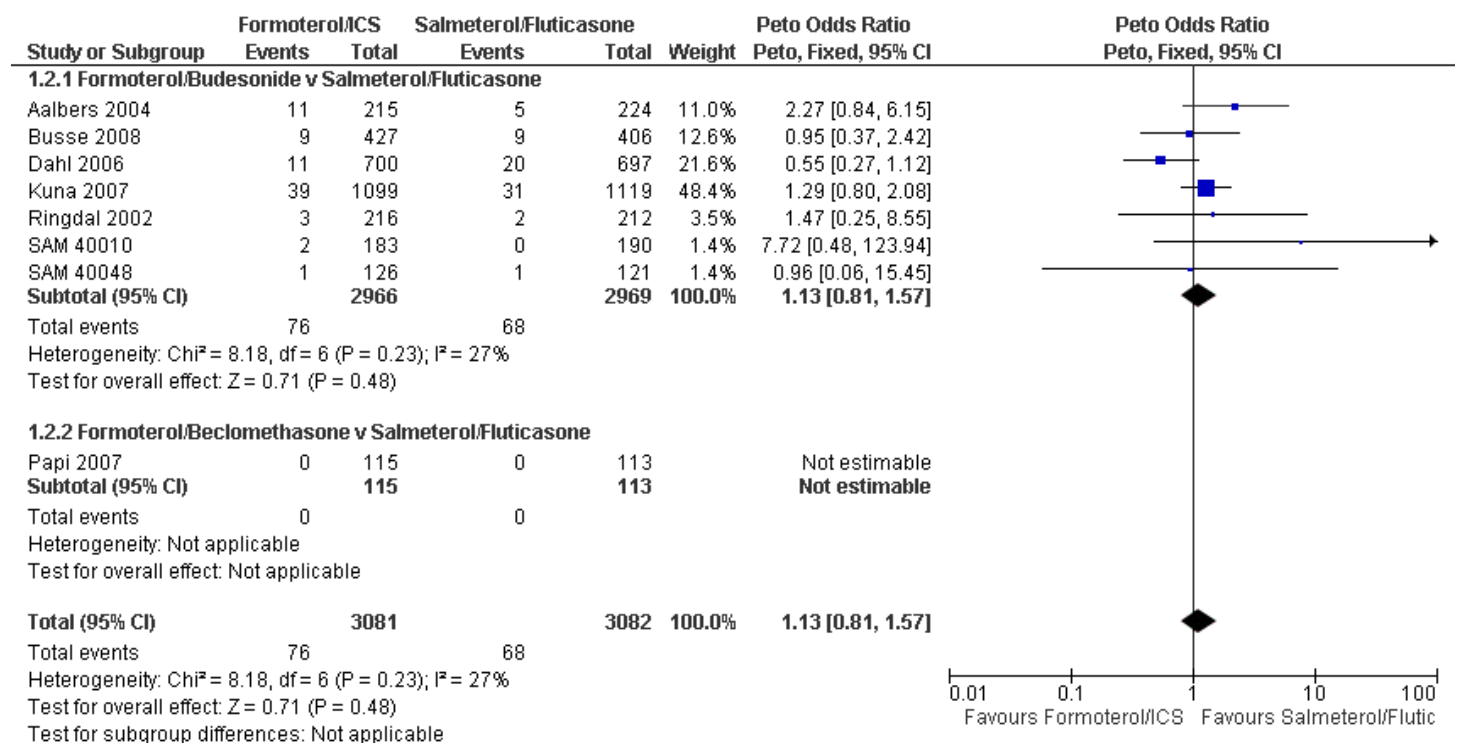

\section{Asthma-related non-fatal serious adverse events}

For two studies we were not able to find published reports of the number of patients who had suffered one or more asthma-related serious adverse events in the paper, but we were able to obtain this information from the sponsor (Busse 2008; Kuna 2007). Overall there were 17 adults and adolescents out of 2966 on formoterol and budesonide with asthma-related serious adverse events, and 25 out of 2969 on salmeterol and fluticasone. This is not a significant difference when combined as an odds ratio (Peto OR 0.69; $95 \%$ CI 0.37 to $1.26, \mathrm{I}^{2}=33 \%$ ) (see Figure 5), or as a risk difference (RD $-0.003 ; 95 \%$ CI -0.007 to $0.002, \mathrm{I}^{2}=0 \%$ ). 
Figure 5. Forest plot of comparison: I Fixed-dose formoterol/ICS versus salmeterol/fluticasone, outcome: I.3 Asthma related non-fatal serious adverse events.

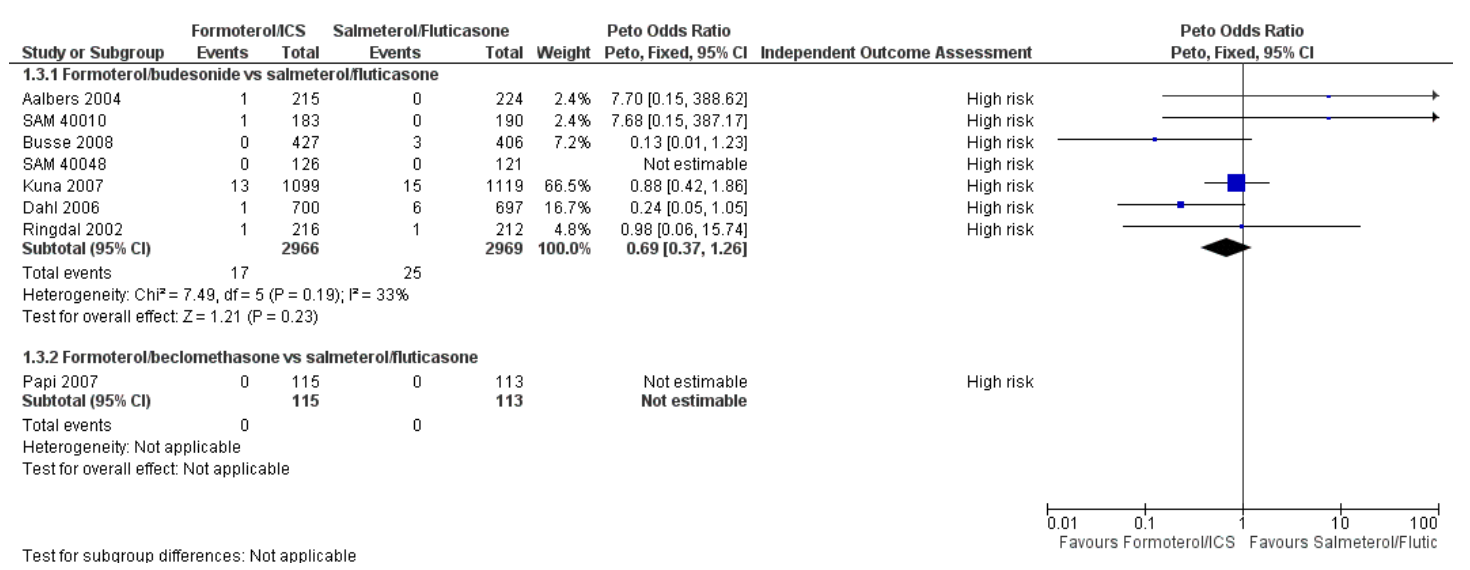

The number of patients who were admitted to hospital in Dahl 2006 on salmeterol and fluticasone was recorded as four, which is lower than the six patients recorded as having asthma-related serious adverse events in this review. The reason for this difference has been clarified following correspondence with GlaxoSmithKline and relates to one patient who suffered acute bronchospasm but was not admitted to hospital, and a second patient who was admitted to hospital but had an exacerbation that had started in the run-in period.

\section{Formoterol/beclomethasone versus salmeterol/fluticasone}

No serious adverse events (fatal or non-fatal) were reported in the single trial in the 228 adult participants from Papi 2007.

\section{Formoterol/mometasone versus salmeterol/fluticasone}

\section{Mortality}

Two deaths occurred in the single study of this comparison (Maspero 2010) and both were taking mometasone (see Figure 2). One was due to electrocution and one due to gastric cancer.

\section{All-cause non-fatal serious adverse events}

There were similar proportions of participants with non-fatal serious adverse events of any cause on both formoterol/mometasone and salmeterol/fluticasone, but the confidence intervals are too wide to conclude that the safety of the two products is equivalent (Peto OR 1.07; 95\% CI 0.40 to 2.84) (see Figure 3).
Asthma-related serious adverse events were not reported from this study.

\section{Formoterol/fluticasone versus salmeterol/fluticasone}

One serious adverse event was reported in each arm of a single study comparing formoterol/fluticasone versus salmeterol/fluticasone in 202 adult participants from Bodzenta-Lukaszyk 2011. The trial report states: "Serious AEs (SAEs) were also reported for one patient in each treatment group. The SAEs experienced by the patient in the fluticasone/formoterol group (haemorrhagic stroke and cardiac arrest, approximately 2 months after randomization) led to withdrawal from the study, and had a fatal outcome. The SAE reported in the fluticasone/salmeterol group was pneumococcal pneumonia."

These numbers are too small to make any meaningful comparison of the relative safety of the two treatments.

\section{Sensitivity analysis}

We carried out sensitivity analysis, excluding the two unblinded studies (Aalbers 2004; Busse 2008). Restricting the analysis to the blinded studies had no impact on mortality (as there were no deaths in either of the open studies). All-cause serious adverse events in the blinded studies showed no significant difference (Peto OR 1.05 ; $95 \%$ CI 0.72 to $1.53, \mathrm{I}^{2}=34 \%$ ), and similarly asthmarelated events were also not significant (Peto OR 0.74; 95\% CI 0.39 to $\left.1.39, \mathrm{I}^{2}=23 \%\right)$.

\section{Subgroup analysis}

Subgroup analysis was not possible on the basis of age, as there were no studies in children. We did not attempt subgroup analysis

Regular treatment with formoterol and an inhaled corticosteroid versus regular treatment with salmeterol and an inhaled corticosteroid $\quad \mathbf{5}$ for chronic asthma: serious adverse events (Review) 
on the basis of dose equivalence of inhaled corticosteroids or longacting beta 2 -agonists as the data were too sparse.

\section{Publication bias}

It was possible to obtain data on serious adverse events from all the studies. A funnel plot was not appropriate as there were fewer than 10 studies included.

\section{ISCUSSION}

\section{Summary of main results}

Ten studies involving adults and adolescents are included in this review. Seven of these $(\mathrm{N}=5935)$ compared formoterol and budesonide to salmeterol and fluticasone, mostly using combined inhalers. One trial $(\mathrm{N}=228)$ compared formoterol and beclomethasone to salmeterol and fluticasone, but this study included no hospital admissions or deaths, so it has not been possible to assess safety for this comparison. One trial $(\mathrm{N}=404)$ compared formoterol and mometasone to salmeterol and fluticasone and one trial $(\mathrm{N}$ = 202) compared formoterol and fluticasone with salmeterol and fluticasone. There were no identified studies in children. The studies recruited participants who were previously treated with moderate to high doses of inhaled steroids.

No significant differences have been found between combination treatment on formoterol with inhaled corticosteroids and salmeterol with fluticasone for all-cause mortality in adults and adolescents, nor for non-fatal adverse events of any cause or events related to asthma.

\section{Overall completeness and applicability of evidence}

Whilst the included studies were sufficiently powered for equivalence in terms of the primary efficacy outcomes (e.g. Papi 2007), they remain underpowered to detect possible important differences in serious adverse events (Cates 2008). Therefore, whilst no significant differences have been found between the combination inhalers, the confidence intervals are too wide to determine equivalence of safety.

\section{Quality of the evidence}

The studies were generally well protected against bias (see Figure 1). Allocation concealment and sequence generation did not present undue risk of bias in the included studies, and results on serious adverse events have been obtained from all the studies. Aalbers 2004, Bodzenta-Lukaszyk 2011, Busse 2008 and Maspero
2010 were open studies, and Aalbers 2004 had a withdrawal rate of over $20 \%$. We carried out sensitivity analysis using only the blinded studies and there was still no significant difference between the treatments. Consideration of asthma-related adverse events might have been subject to bias as none of the trials used independent outcome assessment for causation of adverse events.

\section{Potential biases in the review process}

Since the included studies were designed to assess efficacy, it seems unlikely that publication bias would take the form of whole studies remaining unreported. It is, however, apparent that the reporting of serious adverse events in medical journals is suboptimal (Cates 2008). In this review it has been possible to obtain serious adverse event data from all studies, following correspondence with the trial sponsors. We therefore feel that there is a low risk of publication bias for this review.

\section{Agreements and disagreements with other studies or reviews}

Previous reviews have identified an increased risk of serious adverse events with regular salmeterol (Cates 2008) and regular formoterol (Cates 2008a) when compared to placebo. In contrast, in studies that used randomised inhaled corticosteroids, no significant increase in serious adverse events has been shown with regular salmeterol (Cates 2009a) or regular formoterol (Cates 2009). However, the confidence intervals in the latter reviews were too wide to conclude that the addition of an inhaled corticosteroid renders regular formoterol or salmeterol completely safe. It is in keeping with these latter reviews that we have found no significant difference between regular salmeterol and regular formoterol when used with a randomised inhaled corticosteroid in this review. The results of this review are also similar to Cates 2009b, which found no significant difference between formoterol and salmeterol in which all participants used background (rather than randomised) inhaled corticosteroids.

The negative findings may be partly an issue of statistical power, as very large numbers of patients would need to be randomised to identify small differences between salmeterol and formoterol. We do not have enough information to rule out clinically important differences between salmeterol and formoterol from the available studies, as the events are too sparse to generate tight confidence intervals.

\section{A U THORS' CONCLUSIONS}

Regular treatment with formoterol and an inhaled corticosteroid versus regular treatment with salmeterol and an inhaled corticosteroid 16 for chronic asthma: serious adverse events (Review) 


\section{Implications for practice}

No significant differences have been found between formoterol and budesonide and salmeterol and fluticasone treatment in studies on 5935 adults, nor between formoterol and beclomethasone and salmeterol and fluticasone in 228 adults, nor between formoterol and mometasone and salmeterol and fluticasone in 404 adults, or between formoterol and fluticasone and salmeterol and fluticasone in 202 adults. Small numbers of patients experienced serious adverse events and the confidence intervals around the combined results are wide, so we have not been able to demonstrate whether the products are equivalent in terms of safety.

\section{Implications for research}

No safety studies comparing formoterol and salmeterol have been carried out in children. A large double-blind, double-dummy study in children comparing the combined inhalers with the same inhaled corticosteroid alone (in a four-arm, parallel-group design) is required to assess the relative safety of formoterol and salmeterol in this age group. Further research is also required to clarify the risk-benefit ratio of combination products in adults as well as children

\section{ACKNOWLEDGEMENTS}

We acknowledge the assistance of Matthew Cates with the protocol. We thank Gabriele Nicolini from Chiesi for clarification of the methodology and confirmation of results from Papi 2007, Joe Gray for confirmation of results from data on record at AstraZeneca for Busse 2008 and Kuna 2007, and Richard Follows from GlaxoSmithKline for clarification of the methodology and results from Dahl 2006, Ringdal 2002, SAM 40010 and SAM 40048 .

\section{REF E R E N C E S}

\section{References to studies included in this review}

Aalbers 2004 \{published data only\}

Aalbers R. Fixed or adjustable maintenance-dose budesonide/formoterol compared with fixed maintenancedose salmeterol fluticasone propionate in asthma patients aged [greater-than or equal to] 16 years: post hoc analysis of a randomized, double-blind open-label extension, parallelgroup study. Clinical Drug Investigation 2010; Vol. 30, issue 7:439-51

Aalbers R, Backer V, Kava TT, Welte T, Omenaas ER, Bergqvist PBF, et al.Adjustable dosing with budesonide/ formoterol reduces the rate of asthma exacerbations compared with fixed dosing salmeterol/fluticasone. European Respiratory Society. 2003:2-20.

* Aalbers R, Backer V, Kava TTK, Omenaas ER, Sandstrom T, Jorup C, et al.Adjustable maintenance dosing with budesonide/formoterol compared with fixeddose salmeterol/fluticasone in moderate to severe asthma. Current Medical Research \& Opinion 2004;20(2):225-40. Aalbers R, Harris A, Naya I. Adjustable dosing with budesonide/formoterol achieves sustained guideline 'wellcontrolled asthma' following step down in treatment. European Respiratory Journal 2005;26(Suppl 49):50s. Aalbers R, Welte T, Jorup C. Adjustable maintenance dosing (AMD) with budesonide /formoterol (B/F) meets guideline-defined management goals more effectively than fixed dosing (FD) with $\mathrm{B} / \mathrm{F}$ or salmeterol/fluticasone $(\mathrm{S} / \mathrm{FL})$ [Abstract]. European Respiratory Journal 2004; Vol. 24, issue Suppl 48:311s.

AstraZeneca (SD-039-0686). A randomized, doubledummy, double-blind/open, parallel-group, phase-III, multicentre, 7-month study to assess the efficacy and safety of Symbicort ${ }^{\circledR}$ Turbuhaler ${ }^{\circledR}$ (budesonide/formoterol; 160/
$4.5 \mathrm{mcg}$ delivered dose) given either as standard therapy ( 2 inhalations bid) or with an adjustable dosing regimen (1, 2 or 4 inhalations bid) versus Seretide ${ }^{\mathrm{TM}}$ Diskus ${ }^{\mathrm{TM}}$ (salmeterol/fluticasone; 50/250 mcg metered dose) given as standard therapy ( 1 inhalation bid) in adult and adolescent asthmatic patients. AstraZeneca Clinical Trials Register issue http://www.astrazenecaclinicaltrials.com/Article/ 512577.aspx (Accessed 19 October 2007).

Welte T, Aalbers R, Naya I. Budesonide/formoterol adjustable maintenance dosing (B/F AMD) reduces the burden of asthma more effectively than fixed dosing (FD) with $\mathrm{B} / \mathrm{F}$ or salmeterol/fluticasone (S/FL) [Abstract]. European Respiratory Journal 2004; Vol. 24, issue Suppl 48:508s.

\section{Bodzenta-Lukaszyk 2011 \{published data only\}}

Bodzenta-Lukaszyk A, Dymek A, Mansikka H. Fluticasone propionate/formoterol fumarate combination therapy has a more rapid onset of action than fluticasone propionate/ salmeterol xinafoate in the treatment of asthma: a randomised controlled trial [Abstract]. Thorax 2010; Vol. 65, issue Suppl 4:P24.

Bodzenta-Lukaszyk A, Dymek A, Mansikka H. Fluticasone propionate/formoterol fumarate combination therapy is as effective as fluticasone propionate/salmeterol xinafoate in the treatment of asthma: a randomised controlled trial [Abstract]. Thorax 2010; Vol. 65, issue Suppl 4:P177. Bodzenta-Lukaszyk A, Dymek A, McAulay K, Mansikka H. Fluticasone/formoterol combination therapy is as effective as fluticasone/salmeterol in the treatment of asthma, but has a more rapid onset of action: an open-label, randomized study. BMC Pulmonary Medicine 2011; Vol. 11:28.

Busse 2008 \{published data only\} Ambrose H, Lawrance R, Goldman M. Beta-adrenergic 
receptor gly16arg variation: effect on response to budesonide/formoterol or fluticasone propionate/salmeterol in asthma patients. Chest 2007; Vol. 132, issue 4:478a. AstraZeneca (D5896C00005). A two-stage randomized, open-label, parallel group, phase III, multicenter, 7 month study to assess the efficacy and safety of Symbicort pMDI administered either as fixed or as an adjustable regimen versus a fixed regimen of Advair in subjects 12 years of age and older with asthma. AstraZeneca Clinical Trials Register (http://www.astrazenecaclinicaltrials.com) 2006 (accessed 13 March 2008).

Busse WW, Shah SR, Somerville L, Martin P, Goldman M. Comparison of asthma exacerbations and lung function with adjustable-dose budesonide/formoterol pressurized metereddose inhaler (BUD/FM pMDI), fixed-dose BUD/FM pMDI, and fixed-dose fluticasone/salmeterol dry powder inhaler (FP/SM DPI). http://www.abstracts2view.com/ ats07 (accessed 13 March 2008) 2007:A191.

* Busse WW, Shah SR, Somerville L, Parasuraman B, Martin P, Goldman M. Comparison of adjustable- and fixed-dose budesonide/formoterol pressurized metered-dose inhaler and fixed-dose fluticasone propionate/salmeterol dry powder inhaler in asthma patients. Journal of Allergy \& Clinical Immunology 2008;121(6):1407-14.

Shah SR, Busse WW, McElhattan J, O'Brien CD, Goldman M. Efficacy and tolerability of fixed-dose (FD) and adjustable-dose (AD) budesonide/formoterol pressurized metered-dose inhaler (BUD/FM pMDI) and FD fluticasone propionate/salmeterol dry powder inhaler (FP/SAL DPI) within racial groups [Abstract]. Journal of Allergy and Clinical Immunology 2009; Vol. 123, issue 2 Suppl 1:S80. Shah SR, Busse WW, Somerville L, Martin P, Goldman M. Asthma control with adjustable-and fixed-dose budesonide/ formoterol pressurized metered-dose inhaler (BUD/FM pMDI) and fixed-dose fluticasone/salmeterol dry powder inhaler (FP/SM DPI [Abstract]. American Thoracic Society International Conference, May 18-23, 2007, San Francisco, California, USA 2007:Poster \#K4.

Somerville L, Busse WW, Shah SR, Martin P, Goldman M. Safety of adjustable-dose budesonide (BUD)/formoterol (FM) pressurized metered-dose inhaler (pMDI), fixeddose (BUD/FM pMDI and fixed-dose fluticasone (FP)/salmeterol (SM) dry powder inhaler (DPI) in asthma patients [Abstract]. American Thoracic Society International Conference, May 18-23, 2007, San Francisco, California, USA 2007:Poster \#K3.

\section{Dahl 2006 \{published data only\}}

* Dahl R, Chuchalin A, Gor D, Yoxall S, Sharma R. EXCEL: A randomised trial comparing salmeterol/fluticasone propionate and formoterol/budesonide combinations in adults with persistent asthma. Respiratory Medicine 2006; Vol. 100, issue 7:1152-62.

Dahl R, Chuchalin A, Lindberg A, Jones M, Aggarwal $\mathrm{K}$, Gor D. EXCEL regular maintenance therapy with salmeterol/fluticasone propionate combination (SFC) reduces exacerbations more effectively than the formoterol/ budesonide combination (FBC). European Respiratory
Journal 2004;24(Suppl 48):309s.

Dahl R, Chuchalin A, Ringdal N, Gor D, Jones M. Salmeterol/fluticasone (SFC) reduces moderate/severe exacerbations more effectively than formoterol/budesonide (FBC) with sustained maintenance therapy EXCEL [Abstract]. American Thoracic Society 2005 International Conference; May 20-25; San Diego, California 2005:[C33] [Poster: F68].

GlaxoSmithKline (SAM40040). A twenty-four week, randomised, double-dummy, double-blind, parallel group study to compare the rate of asthma exacerbations between SERETIDE DISKUS 50/250ig 1 inhalation bd and formoterol/budesonide Breath-Actuated Dry Powder Inhaler (BADPI) 4.5/160ìg 2 inhalations bd in subjects with moderate to severe asthma. GlaxoSmithKline Clinical Trials Register issue http://ctr.gsk.co.uk/Summary/ fluticasone' salmeterol/IV·SAM40040.pdf (accessed 19 October 2007).

\section{Kuna 2007 \{published data only\}}

AstraZeneca (SD-0390735). Comparison of the efficacy and safety of one inhalation of Symbicort ${ }^{\circledR}$ Turbuhaler ${ }^{\circledR}$ $160 / 4.5 \mu \mathrm{g}$ bid plus as-needed with two inhalations of SeretideTM EvohalerTM 25/125 $\mu \mathrm{g}$ bid plus Terbutaline Turbuhaler ${ }^{\circledR} 0.4 \mathrm{mg}$ as-needed, and one inhalation of Symbicort ${ }^{\circledR}$ Turbuhaler ${ }^{\circledR} 320 / 9 \mu \mathrm{g}$ bid plus Terbutaline Turbuhaler ${ }^{\circledR} 0.4 \mathrm{mg}$ as-needed. A 6-month, randomised, double-blind, double-dummy, parallel-group, active-controlled,Multicentre, phase IIIB study in adult and adolescent asthmatic patients.. http: //www.astrazenecaclinicaltrials.com/' mshost2715844/ content/content/resources/media/2958892/sd-0390735.pdf (accessed 30 April 30 2009).

Bleecker ER, Postma DS, Lawrance R, Meyers DA, Ambrose H, Goldman M. Effect of polymorphisms in the beta2-adrenergic receptor gene (ADRB2) on response to long-acting beta2-agonist (LABA) therapy. Journal Allergy and Clinical Immunology 2007;119(2):523.

Buhl R, Kuna P. Does the choice of ICS/LABA regimen influence exacerbation rates in asthma patients with high as needed use? [Abstract]. European Respiratory Journal 2007; Vol. 30, issue Suppl 51:617s [P3620].

Kuna P. Treatment comparison of budesonide formoterol with salmeterol fluticasone propionate in adults aged >= 16 years with asthma: post hoc analysis of a randomized, double-blind study. Clinical Drug Investigation 2010; Vol. 30, issue 9:565-79.

Kuna P, Peters J, Buhl R. Budesonide/formoterol as maintenance and reliever therapy reduces asthma exacerbations versus higher maintenance dose of budesonide/formoterol or salmeterol/fluticasone [Abstract]. European Respiratory Journal 2006; Vol. 28, issue Suppl 50:205s [P1228].

* Kuna P, Peters MJ, Manjra AI, Jorup C, Naya IP, Martinez-Jimenez NE, et al.Effect of budesonide/formoterol maintenance and reliever therapy on asthma exacerbations. International Journal of Clinical Practice 2007; Vol. 61, 
issue 5:725-36.

Miller E, FitzGerald JM. Budesonide/formoterol as maintenance and reliever treatment compared to fixed dose combination strategies - a Canadian economic evaluation. Canadian Journal of Clinical Pharmacology/Journal Canadien de Pharmacologie Clinique 2008; Vol. 15, issue 2:e165-76.

Price D, Wiren A, Kuna P. Cost-effectiveness of budesonide/ formoterol for maintenance and reliever asthma therapy. Allergy: European Journal of Allergy and Clinical Immunology 2007; Vol. 62, issue 10:1189-98. Tamminen K, Laine J, Soini E, Martikainen J, Kankaanranta H. Cost-effectiveness analysis of budesonide/formoterol maintenance and reliever therapy versus fixed combination treatments for asthma in Finland. Current Medical Research and Opinion 2008;24(12):3453-61.

\section{Maspero 2010 \{published data only\}}

FDA (Susan Limb). Clinical Review of Dulera (NDA 22518). www.fda.gov/downloads/Drugs/.../UCM224593.pdf (22 January 2010).

Maspero J, Cherrez I, Nolte H. Long-term safety and tolerability of two doses of mometasone furoate/formoterol (MF/F) combination, administered via a metered-dose inhaler, for the treatment of moderate-to-severe persistent asthma [Abstract]. Journal of Allergy and Clinical Immunology 2009; Vol. 123, issue 2 Suppl 1:S159. Maspero J, Cherrez I, Nolte H. Mometasone furoate/ formoterol $(\mathrm{mf} / \mathrm{f})$ combination treatment in patients with moderate-to-severe asthma: findings from a 1-yr safety trial [Abstract]. European Respiratory Society Annual Congress, Vienna, Austria, September 12-16 2009:[E274]. Maspero J, Nolte H, Cherrez I. Long-term safety of medium- and high-dose mometasone furoate/formoterol combination in persistent asthmatics: analysis of adverse event incidence, plasma cortisol, and ocular changes [Abstract]. European Respiratory Society Annual Congress, Barcelona, Spain, September 18-22 2010:[P1211]. Maspero J, Nolte H, Ojeda IC. Long-term safety of medium- and high-doses mometasone furoate/formoterol combination in persistent asthmatics: analysis of adverse events incidence, plasma cortisol, and ocular changes [Abstract]. Journal of Allergy and Clinical Immunology 2010; Vol. 125, issue 2 Suppl 1:AB197.

Maspero JF, Cherrez I, Nolte H. Mometasone furoate and formoterol (MF/F) combination administered via a metered-dose inhaler (MDI) for the treatment of asthma: results from a 1-yr safety study [Abstract]. American Thoracic Society International Conference, May 15-20, 2009, San Diego 2009:A2768 [Poster \#J37].

* Maspero JF, Nolte H, Cherrez-Ojeda I. Long-term safety of mometasone furoate formoterol combination for treatment of patients with persistent asthma. Journal of Asthma 2010; Vol. 47, issue 10:1106-15.

Papi 2007 \{published data only\} Paggiaro P, Papi A, Feschenko YI, Nicolini G, Fabbri LM. Efficacy and safety of the new beclomethasone dipropionate/ formoterol combination vs fluticasone propionate/ salmeterol pMDIs in moderate to severe persistent asthma [Abstract]. European Respiratory Journal 2006; Vol. 28, issue Suppl 50:205s [P1227].

* Papi A, Paggiaro P, Nicolini G, Vignola AM, Fabbri LM. Beclomethasone/formoterol vs fluticasone/salmeterol inhaled combination in moderate to severe asthma. Allergy: European Journal of Allergy and Clinical Immunology 2007; 62(10):1182-8.

\section{Ringdal 2002 \{published data only\}}

Jenkins C, Wilson J, Rutherford C, Perry AS, Whitehead PJ. Asthma management costs are lower with combination fluticasone/salmeterol $(25 / 50 \mathrm{mcg} B D)$ in a single inhaler than with budesonide ( $800 \mathrm{mcg} \mathrm{BD}$ ) plus eformoterol (12 mcg BD) via separate inhalers. Respirology 2002; Vol. 7, issue Supplement:A20 Abstract number (P23).

Martin AA, Whitehead PJ, McCarthy TP. Asthma costs with salmeterol/fluticasone combination $50 / 250 \mathrm{mcg}$ bd compared to budesonide $800 \mathrm{mcg}$ bd plus formoterol $12 \mathrm{mcg}$ bd [abstract]. American Thoracic Society 99th International Conference. 2003:D034 Poster C43.

Ringdal N, Chovan L, Chuchalin AG, Whitehead PJ. Advair $^{\mathrm{TM}} / \mathrm{Seretide}^{\mathrm{TM}}(250 \mu \mathrm{g} / 50 \mu \mathrm{g}$ bid $)$ shows exacerbation benefit over budesonide $800 \mu \mathrm{g}+$ formoterol $12 \mu \mathrm{g}$ in moderate-severe asthma [abstract]. American Journal of Respiratory and Critical Care Medicine 2001; Vol. 163, issue Suppl 5:A866.

* Ringdal N, Chuchalin A, Chovan L, Tudoric N, Maggi E, Whitehead PJ, et al.Evaluation of different inhaled combination therapies (EDICT): a randomised, doubleblind comparison of Seretide (50/250 mug bd Diskus vs. formoterol (12 mug bd) and budesonide (800 mug bd) given concurrently (both via Turbuhaler) in patients with moderate-to-severe asthma. Respiratory Medicine 2002;96 (11):851-61.

Ringdal N, Chuchalin AG, Chovan L, Whitehead PJ. A comparison of Advair ${ }^{\mathrm{TM}} / \mathrm{Seretide}^{\mathrm{TM}}$ (salmeterol $50 \mu \mathrm{g}$ / fluticasone propionate $250 \mu \mathrm{g}$ bid) with formoterol 12 $\mu \mathrm{g}+$ budesonide $800 \mu \mathrm{g}$ bid in moderate-severe asthma [abstract]. American Journal of Respiratory and Critical Care Medicine 2000; Vol. 161, issue Suppl 3:A196. Rodriguez JM, Sondhi S, Suppl. Economic evaluation of salmeterol/fluticasone propionate combination vs budesonide/formoterol in Spain [Abstract]. European Respiratory Journal. Supplement. 2003; Vol. 22 (Suppl 45):Abstract No: [2255].

Sondhi S, Martin A. Economic evaluation of salmeterol/ fluticasone propionate combination versus budesonide/ formoterol in the UK [Abstract]. American Thoracic Society 99th International Conference. 2003:[B106] Poster E5.

\section{SAM 40010 \{published data only\}}

GlaxoSmithKline. A randomised, double blind, doubledummy, parallel-group, twelve week comparison of salmeterol/fluticasone propionate (FP) DISKUS/ ACCUHALER 50/100mcg bd. with budesonide $200 \mathrm{mcg}$ bd. plus formoterol $4.5 \mathrm{mcg}$ bd. (both by breath-activated dry powder inhaler [BADPI]) in adult and adolescent 
asthmatics. www.clinicalstudyresults.org 2004.

SAM 40048 \{published data only\}

GlaxoSmithKline. Randomised, double-blind, parallel group study on the efficacy and tolerability of the salmeterol $50 \mathrm{mcg} /$ fluticasone $250 \mathrm{mcg}$ combination Diskus compared to the formoterol $6 \mathrm{mcg} /$ budesonide $200 \mathrm{mcg}$ combination Turbohaler administered twice daily in patients with moderate bronchial asthma. GlaxoSmithKline Clinical Trial Register 2005.

\section{References to studies excluded from this review}

\section{Bleecker 2008 \{published data only\}}

Bleecker ER, Postma DS, Lawrance RM, Meyers DA, Ambrose HJ, Goldman M. Effect of ADRB2 polymorphisms on response to long acting beta2-agonist therapy: a pharmacogenetic analysis of two randomised studies. [see comment]. [Review] [33 refs]. Comment in: Lancet. 2008 Dec 22;370(9605):2075-6; PMID: 18156014. Lancet 2008; Vol. 370, issue 9605:2118-25.

\section{Dhillon 2006 \{published data only\}}

Dhillon S, Keating GM. Beclometasone dipropionate/ formoterol: in an HFA-propelled pressurised metered-dose inhaler. Drugs 2006; Vol. 66, issue 11:1475-83.

\section{Hampel 2008 \{published data only\}}

\section{Hampel FC, Martin P, Mezzanotte WS. Early} bronchodilatory effects of budesonide/formoterol pMDI compared with fluticasone/salmeterol DPI and albuterol pMDI: 2 randomized controlled trials in adults with persistent asthma previously treated with inhaled corticosteroids. Journal of Asthma 2008; Vol. 45, issue 4: $265-72$.

Jung 2008 \{published data only\} Jung KS, Uh ST, Lee YC, Shim JJ, Park SK, Williams $\mathrm{AE}$, et al.Comparison of the clinical efficacy and safety of salmeterol/fluticasone propionate versus current care in the management of persistent asthma in Korea. Current Medical Research \& Opinion 2008; Vol. 24, issue 12: 3571-82.

Lee 2003 \{published data only\} Lee DKC, Currie GP, Cockburtn WJ, Lipworth BJ. Comparison of budesonide/formoterol versus fluticasone/ salmeterol combination inhalers in moderate persistent asthma [abstract]. American Thoracic Society 99th International Conference 2003:D094 Poster 613.

Lyseng-Williamson 2003 \{published data only\} Lyseng-Williamson KA, Plosker GL. Inhaled salmeterol/ fluticasone propionate combination: a pharmacoeconomic review of its use in the management of asthma. Pharmacoeconomics 2003; Vol. 21, issue 13:951-89.

\section{Additional references}

Altman 2003

Altman DG, Bland JM. Statistics notes: interaction revisited: the difference between two estimates. BMJ 2003; 326(7382):219.

\section{Barnes 2002}

Barnes PJ. Scientific rationale for inhaled combination therapy with long-acting beta2-agonists and corticosteroids. European Respiratory Journal 2002;19:182-91.

\section{Beach 1992}

Beach JR, Young CL, Stenton SC, Avery AJ, Walters EH, Hendrick DJ. A comparison of the speeds of action of salmeterol and salbutamol in reversing methacholineinduced bronchoconstriction. Pulmonary Pharmacology 1992;5(2):133-5.

\section{Cates 2008}

Cates CJ, Cates MJ. Regular treatment with salmeterol for chronic asthma: serious adverse events. Cochrane Database of Systematic Reviews 2008, Issue 3. [DOI: 10.1002/ 14651858.CD006363.pub2]

\section{Cates 2008a}

Cates CJ, Cates MJ, Lasserson TJ. Regular treatment with formoterol for chronic asthma: serious adverse events. Cochrane Database of Systematic Reviews 2008, Issue 4. [DOI: 10.1002/14651858.CD006923.pub2]

\section{Cates 2009}

Cates CJ, Lasserson TJ, Jaeschke R. Regular treatment with formoterol and inhaled steroids for chronic asthma: serious adverse events. Cochrane Database of Systematic Reviews 2009, Issue 2. [DOI: 10.1002/ 14651858.CD006924.pub2]

\section{Cates 2009a}

Cates CJ, Lasserson TJ, Jaeschke R. Regular treatment with salmeterol and inhaled steroids for chronic asthma: serious adverse events. Cochrane Database of Systematic Reviews 2009, Issue 3. [DOI: 10.1002/ 14651858.CD006922.pub2]

\section{Cates 2009b}

Cates CJ, Lasserson TJ. Regular treatment with formoterol versus regular treatment with salmeterol for chronic asthma: serious adverse events. Cochrane Database of Systematic Reviews 2009, Issue 4. [DOI: 10.1002/ 14651858.CD007695.pub2]

Ducharme 2010

Ducharme FM, Ni Chroinin M, Greenstone I, Lasserson TJ. Addition of long-acting beta2-agonists to inhaled steroids versus higher dose inhaled steroids in adults and children with persistent asthma. Cochrane Database of Systematic Reviews 2010, Issue 4. [DOI: 10.1002/ 14651858.CD005533.pub2]

\section{Ducharme 2011}

Ducharme FM, Lasserson TJ, Cates CJ. Addition to inhaled corticosteroids of long-acting beta2-agonists versus anti-leukotrienes for chronic asthma. Cochrane Database of Systematic Reviews 2011, Issue 5. [DOI: 10.1002/ 14651858.CD003137.pub4]

\section{Giembycz 2006}

Giembycz MA, Newton R. Beyond the dogma: novel ß2adrenoceptor signalling in the airways. European Respiratory Journal 2006;27(6):1286-306.

Regular treatment with formoterol and an inhaled corticosteroid versus regular treatment with salmeterol and an inhaled corticosteroid 20 for chronic asthma: serious adverse events (Review) 
Higgins 2008

Higgins JPT, Green S, editors. Cochrane Handbook for Systematic Reviews of Interventions Version 5.0.1 [updated September 2008]. Chichester: John Wiley \& Sons, 2008.

\section{ICHE2a 1995}

Expert Working Group (Efficacy) of the International Conference on Harmonisation of Technical Requirements for Registration of Pharmaceuticals for Human Use (ICH). Clinical safety data management: definitions and standards for expedited reporting. http://www.fda.gov/cder/guidance/ iche2a.pdf 1995.

\section{Lasserson 2008}

Lasserson TJ, Cates CJ, Ferrara G, Casali L. Combination fluticasone and salmeterol versus fixed dose combination budesonide and formoterol for chronic asthma in adults and children. Cochrane Database of Systematic Reviews 2008, Issue 1. [DOI: 10.1002/14651858.CD004106.pub3]

\section{Lipworth 1997}

Lipworth BJ. Airway sub-sensitivity with long-acting beta 2-agonists: is there cause for concern?. Drug Safety 1997;16 (5):295-308

\section{Ni Chroinin 2009}

Ni Chroinin M, Greenstone I, Lasserson TJ, Ducharme FM. Addition of inhaled long-acting beta2-agonists to inhaled steroids as first line therapy for persistent asthma in steroid-naive adults. Cochrane Database of Systematic Reviews 2009, Issue 4. [DOI: 10.1002/14651858.CD005307]

\section{Ni Chroinin 2010}

Ducharme FM, Ni Chroinin M, Greenstone I, Lasserson TJ. Addition of long-acting beta2-agonists to inhaled corticosteroids versus same dose inhaled corticosteroids for chronic asthma in adults and children. Cochrane Database of Systematic Reviews 2010, Issue 5. [DOI: 10.1002/ 14651858.CD005535.pub2]

\section{RevMan 5}

The Nordic Cochrane Centre: The Cochrane Collaboration. Review Manager (RevMan) Version 5.1. Copenhagen: The Nordic Cochrane Centre: The Cochrane Collaboration, 2008.

\section{Salpeter 2006}

Salpeter SR, Buckley NS, Ormiston TM, Salpeter EE. Meta-analysis: effect of long-acting beta-agonists on severe asthma exacerbations and asthma-related deaths. Annals of Internal Medicine 2006;144(12):904-12.

\section{SMART 2006}

Nelson HS, Weiss ST, Bleecker ER, Yancey SW, Dorinsky PM, the SMART Study Group. The Salmeterol Multicenter Asthma Research Trial: a comparison of usual pharmacotherapy for asthma or usual pharmacotherapy plus salmeterol. Chest 2006;129:15-26.

Walters 2002

Walters EH, Walters JAE, Gibson PW. Regular treatment with long acting beta agonists versus daily regular treatment with short acting beta agonists in adults and children with stable asthma. Cochrane Database of Systematic Reviews 2002, Issue 3. [DOI: 10.1002/14651858.CD003901]

Walters 2007

Walters EH, Gibson PG, Lasserson TJ, Walters JAE. Longacting beta2-agonists for stable chronic asthma. Cochrane Database of Systematic Reviews 2007, Issue 1. [DOI: 10.1002/14651858.CD001385.pub2]

* Indicates the major publication for the study 
CHARACTERISTICS OF STUDIES

Characteristics of included studies [ordered by study ID]

Aalbers 2004

Methods

A randomised, double-blind/open-extension, double-dummy, multicentre, parallelgroup study over 4 weeks from October 2001 to December 2002 at outpatient clinics in 93 centres in 6 countries (Denmark (9), Finland(10), Germany (11), the Netherlands (12), Norway (41) and Sweden (10)). Open run-in 10 to 14 days)

The open extension period was for 6 months in which 2 arms of the study continued on fixed-dose BDF and FPS

Participants

658 adolescents and adults (12 to 85 ) years with perennial asthma

Baseline characteristics: mean age 46 years. FEV $_{1} 84 \%$ predicted. Concomitant inhaled corticosteroids used by $100 \%$ of participants, mean dose $735 \mu$ g/day. Run-in on previous dose of ICS alone (LABA discontinued in the $28 \%$ of participants taking it previously) Inclusion criteria: aged 12 years or over with a diagnosis of perennial asthma and using between 500 to $1200 \mu \mathrm{g}$ daily of inhaled GCS. $\mathrm{FEV}_{1} \%$ predicted of $50 \%$ or greater. Must have had a total asthma symptom score of at least 1 on at least 4 of the last 7 days of the run-in period and a mean morning peak expiratory flow (PEF) during the last 7 days of the run-in period of between $50 \%$ and $85 \%$ of post bronchodilatory PEF measured at Visit 1 or 2. Run-in on previous ICS alone

Exclusion criteria: respiratory infection affecting asthma within 1 month of study entry, smoking history of more than 10 pack-years, use of systemic corticosteroids within 1 month of study entry and any significant disorder which, in the opinion of the investigator, may have put the patient at risk or influenced the study

\begin{tabular}{|c|c|}
\hline Interventions & $\begin{array}{l}\text { 1. Salmeterol/fluticasone } 50 / 250 \mu \mathrm{g} \text { bd } \times 1 \text { DPI } \\
\text { 2. Budesonide/formoterol } 160 / 4.5 \mu \mathrm{g} \text { bd } \times 2 \text { DPI } \\
\text { 3. The third arm was on adjustable maintenance dose and not used in this review }\end{array}$ \\
\hline
\end{tabular}

Outcomes

The primary efficacy endpoint was the odds of having a well-controlled asthma week during the randomised treatment period. SAE reported in the paper for each group. No deaths occurred in the study (web report)

\begin{tabular}{ll} 
Notes Sponsored by AstraZeneca \\
\hline
\end{tabular}

\section{Risk of bias}

\begin{tabular}{l|l|l}
\hline Bias & Authors' judgement & Support for judgement \\
\hline $\begin{array}{l}\text { Random sequence generation (selection } \\
\text { bias) }\end{array}$ & Low risk & $\begin{array}{l}\text { The randomisation schedule was generated } \\
\text { using a computer program by a statistician } \\
\text { independent of the study team }\end{array}$ \\
\hline Allocation concealment (selection bias) & Low risk & $\begin{array}{l}\text { Patients were consecutively allocated to the } \\
\text { lowest available patient number and were } \\
\text { randomised strictly sequentially in blocks }\end{array}$
\end{tabular}

Regular treatment with formoterol and an inhaled corticosteroid versus regular treatment with salmeterol and an inhaled corticosteroid 22 for chronic asthma: serious adverse events (Review)

Copyright (? 201 I The Cochrane Collaboration. Published by John Wiley \& Sons, Ltd. 


\begin{tabular}{|c|c|c|}
\hline $\begin{array}{l}\text { Blinding of participants and personnel } \\
\text { (performance bias) } \\
\text { All outcomes }\end{array}$ & High risk & $\begin{array}{l}\text { No blinding in the } 6 \text {-month open exten- } \\
\text { sion period }\end{array}$ \\
\hline $\begin{array}{l}\text { Blinding of outcome assessment (detection } \\
\text { bias) } \\
\text { All outcomes }\end{array}$ & Unclear risk & No details \\
\hline $\begin{array}{l}\text { Incomplete outcome data (attrition bias) } \\
\text { All outcomes }\end{array}$ & Unclear risk & $\begin{array}{l}575 / 658(76 \%) \text { completed the study, with } \\
\text { similar loss in all groups }\end{array}$ \\
\hline Selective reporting (reporting bias) & Low risk & SAE reported in paper for each group \\
\hline $\begin{array}{l}\text { Independent Outcome Assessment } \\
\text { Asthma-related serious adverse events }\end{array}$ & High risk & No independent outcome assessment \\
\hline
\end{tabular}

Bodzenta-Lukaszyk 2011

Methods

Study design: this was a 12-week, open-label, randomised, active-controlled, parallelgroup, phase 3 study, conducted at 25 centres across 5 European countries (Germany, Hungary, Poland, Romania and the UK; clinicaltrials.gov identifier: NCT00476073)

Participants
Population: 202 adults $(18+)$ years with patients with mild-to-moderate-to-severe per-
Baseline characteristics: mean age 47 years. $\mathrm{FEV}_{1}$ 67\% predicted. Concomitant inhaled
corticosteroids used by $93 \%$ of participants
Inclusion criteria: patients were required to demonstrate a $\mathrm{FEV}_{1}$ of $\geq 40 \%$ and $\leq$
$85 \%$ of predicted normal values $(17)$ during the screening phase following appropriate
withholding of asthma medications (if applicable). Patients were also required to show
reversibility of $\geq 15 \%$ in $F E V_{1}$ after salbutamol inhalation ( 2 actuations, $100 \mu \mathrm{g}$ per
actuation) in order to be eligible for randomisation. Only patients who could demonstrate
correct inhaler technique were entered into the study
Exclusion criteria: life-threatening asthma within the past year; hospitalisation or emer-
gency department visit for asthma in the 4 weeks prior to screening; systemic corticos-
teroid use in the month prior to screening; omalizumab use in the past 6 months; use
of a leukotriene receptor antagonist in the week before screening; a smoking history
that was either recent (in the 12 months prior to screening) or equivalent to $\geq 10$ pack
years (e.g. at least 20 cigarettes/day for 10 years); significant non-reversible active pul-
monary disease; and clinically significant respiratory tract infection in the 4 weeks prior
to screening. Also prohibited was recent use (in the past week) of b-blocking agents, tri-
cyclic antidepressants, monoamine oxidase inhibitors, astemizole, quinidine-type anti-
arrhythmics or potent CYP3A4 inhibitors. Current use of medications that would have
an effect on bronchospasm and/or lung function was also a criterion for exclusion


Bodzenta-Lukaszyk 2011 (Continued)

\begin{tabular}{|c|c|c|}
\hline & \multicolumn{2}{|c|}{$\begin{array}{l}\text { Both study treatments were administered via a hydrofluoroalkane pressurised metered- } \\
\text { dose inhaler with an AeroChamber }{ }^{\circledR} \text { Plus spacer device } \\
\text { Patients receiving the low dose of study medication were permitted to switch to the high } \\
\text { dose during the treatment period if their asthma was not controlled, at the investigator's } \\
\text { discretion }\end{array}$} \\
\hline Outcomes & \multicolumn{2}{|c|}{$\begin{array}{l}\text { Primary outcome: } \mathrm{FEV}_{1} \\
\text { SAE results reported in the paper: } \\
\text { "Serious AEs (SAEs) were also reported for one patient in each treatment group. The SAEs } \\
\text { experienced by the patient in the fluticasone/formoterol group (haemorrhagic stroke and } \\
\text { cardiac arrest, approximately } 2 \text { months after randomization) led to withdrawal from the } \\
\text { study, and had a fatal outcome. The SAE reported in the fluticasone/ salmeterol group } \\
\text { was pneumococcal pneumonia." }\end{array}$} \\
\hline Notes & \multicolumn{2}{|c|}{ Sponsored by Mundipharma Research Limited } \\
\hline \multicolumn{3}{|l|}{ Risk of bias } \\
\hline Bias & Authors' judgement & Support for judgement \\
\hline $\begin{array}{l}\text { Random sequence generation (selection } \\
\text { bias) }\end{array}$ & Low risk & Random permuted block design \\
\hline Allocation concealment (selection bias) & Low risk & $\begin{array}{l}\text { Eligible patients were assigned a unique } \\
\text { randomisation number selected sequen- } \\
\text { tially from a randomisation list via an in- } \\
\text { teractive voice randomisation system }\end{array}$ \\
\hline $\begin{array}{l}\text { Blinding of participants and personnel } \\
\text { (performance bias) } \\
\text { All outcomes }\end{array}$ & High risk & Open-label \\
\hline $\begin{array}{l}\text { Blinding of outcome assessment (detection } \\
\text { bias) } \\
\text { All outcomes }\end{array}$ & Unclear risk & No details \\
\hline $\begin{array}{l}\text { Incomplete outcome data (attrition bias) } \\
\text { All outcomes }\end{array}$ & Low risk & $7 \%$ and $6 \%$ withdrawn from each arm \\
\hline Selective reporting (reporting bias) & Low risk & $\begin{array}{l}\text { SAE events reported in paper for each } \\
\text { group }\end{array}$ \\
\hline $\begin{array}{l}\text { Independent Outcome Assessment } \\
\text { Asthma-related serious adverse events }\end{array}$ & High risk & $\begin{array}{l}\text { No independent outcome assessment re- } \\
\text { ported }\end{array}$ \\
\hline
\end{tabular}

Regular treatment with formoterol and an inhaled corticosteroid versus regular treatment with salmeterol and an inhaled corticosteroid 


\begin{tabular}{|c|c|}
\hline Methods & $\begin{array}{l}\text { Study design: a randomised, open-label, multicentre, parallel-group, Phase III study } \\
\text { over } 7 \text { months at } 145 \text { centres in the United States. Run-in } 10 \text { to } 14 \text { days. } \\
\text { The study comprised } 3 \text { phases: run-in ( } 10 \text { to } 14 \text { days), treatment period } 1 \text { ( } 1 \text { month, fixed- } \\
\text { dose regimens), treatment period } 2 \text { ( } 6 \text { months, adjustable-dose or fixed-dose regimens). }\end{array}$ \\
\hline
\end{tabular}

Participants

Population: 1225 adolescents and adults (12 to 87 ) years with moderate-to-severe persistent asthma

Baseline characteristics: mean age 39 years. $\mathrm{FEV}_{1} 78.7 \%$ predicted. Concomitant inhaled corticosteroids used by $100 \%$ of participants. Mean dose $550 \mu \mathrm{g} /$ day. Run-in on previous asthma therapy (ICS or LABA/ICS)

Inclusion criteria: patients aged 12 years and older with a documented diagnosis of asthma, as defined by the American Thoracic Society for 6 months or more before screening and who were in stable condition. To have been maintained on a daily mediumdose ICS or ICS/LABA combination for 12 weeks or longer before screening. FEV $1 \%$ predicted of $50 \%$ or greater 6 or more hours after short-acting beta 2 -adrenergic agonist use and 24 or more hours after LABA use, had received 8 or more inhalations of albuterol during the last 10 days of the run-in period and demonstrated a mean morning peak expiratory flow (PEF) of between $50 \%$ and $85 \%$ of the PEF value obtained 15 minutes after albuterol pMDI ( 2 to 4 inhalations $(90 \mu \mathrm{g}$ per inhalation) ) during the last 7 days of the run-in period.

Exclusion criteria: systemic corticosteroid use within 30 days before screening, a 20 or more pack-year smoking history at screening, or a significant disease, respiratory tract infection, or illness that might interfere with the patient's lung function or participation in the study

Interventions

1. Fluticasone/salmeterol $250 / 50 \mu \mathrm{g}$ BD DPI

2. Budesonide/formoterol 320/9 $\mu \mathrm{g}$ BD pMDI

The AMD treatment arm was not included in this review

Outcomes

The primary efficacy variable was asthma control, as assessed by asthma exacerbations SAE results reported on the sponsor's website. Uncertainty over the 2 participants mentioned in the footnotes to table $\mathrm{S} 4$ in the report from the trial register was resolved after correspondence with the sponsors. The participant who suffered a SAE after finishing treatment had already been counted in the formoterol/budesonide arm due to another SAE whilst on treatment, but the patient who was admitted to hospital for an episode that was judged to have started during run-in had not been included in the 9 participants on formoterol/budesonide. After discussion we therefore used 10 for this arm in our primary analysis

Notes Sponsored by AstraZeneca

Risk of bias

\begin{tabular}{|c|c|c|}
\hline & & Authors' judgement \\
\hline
\end{tabular}

Random sequence generation (selection Low risk bias)
The randomisation schedule was computer-generated 
Busse 2008 (Continued)

\begin{tabular}{|c|c|c|}
\hline Allocation concealment (selection bias) & Low risk & $\begin{array}{l}\text { The site called in to an IVRS which as- } \\
\text { signed subjects the next lowest available } \\
\text { randomisation number }\end{array}$ \\
\hline $\begin{array}{l}\text { Blinding of participants and personnel } \\
\text { (performance bias) } \\
\text { All outcomes }\end{array}$ & High risk & No blinding in 6-month study extension \\
\hline $\begin{array}{l}\text { Blinding of outcome assessment (detection } \\
\text { bias) } \\
\text { All outcomes }\end{array}$ & Unclear risk & No details \\
\hline $\begin{array}{l}\text { Incomplete outcome data (attrition bias) } \\
\text { All outcomes }\end{array}$ & Low risk & $1052 / 1225(86 \%)$ completed the study \\
\hline Selective reporting (reporting bias) & Low risk & SAE data found on website \\
\hline $\begin{array}{l}\text { Independent Outcome Assessment } \\
\text { Asthma-related serious adverse events }\end{array}$ & High risk & No independent outcome assessment \\
\hline
\end{tabular}

\section{Dahl 2006}

Methods

Study design: a randomised, double-blind, double-dummy, multicentre, parallel-group study over 24 weeks from November 2001 to January 2003 at 178 centres in 18 European countries. Run-in 2 weeks

\begin{tabular}{|c|c|}
\hline Participants & 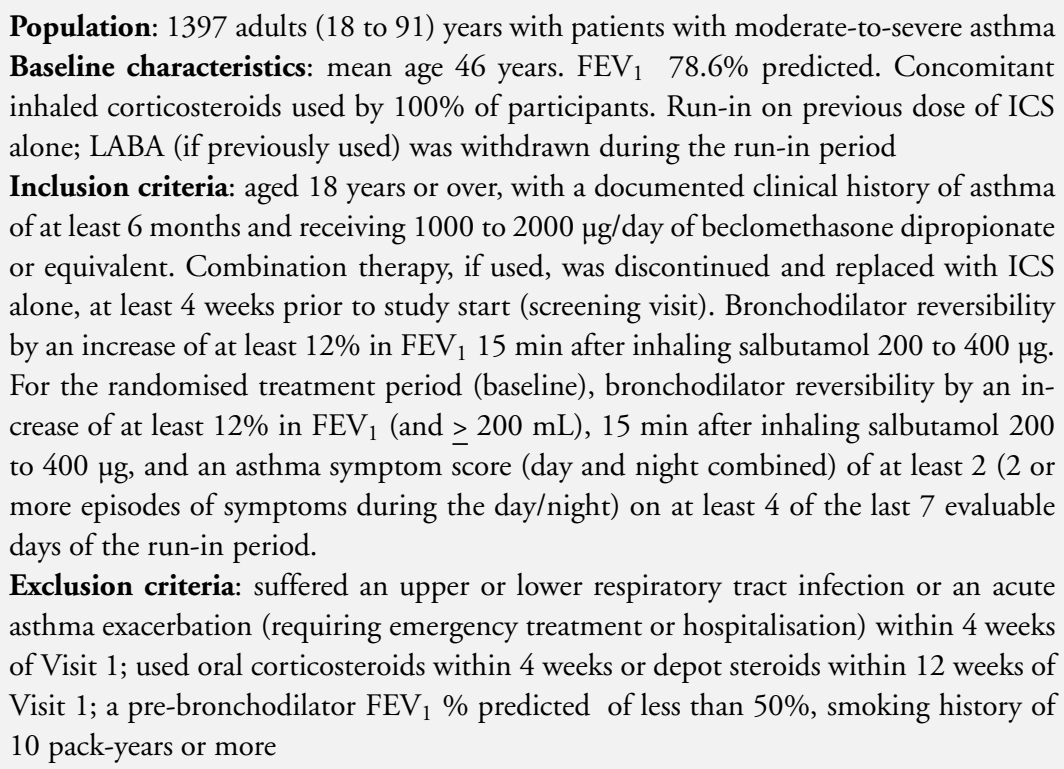 \\
\hline Interventions & $\begin{array}{l}\text { 1. Salmeterol/fluticasone } 50 / 250 \mu \mathrm{g} \text { bdx } 1 \mathrm{DPI} \\
\text { 2. Formoterol/budesonide } 6 / 200 \mu \mathrm{g} \text { bdx } 2 \mathrm{DPI}\end{array}$ \\
\hline
\end{tabular}

Regular treatment with formoterol and an inhaled corticosteroid versus regular treatment with salmeterol and an inhaled corticosteroid 
Dahl 2006 (Continued)

\begin{tabular}{ll}
\hline Outcomes & $\begin{array}{l}\text { The primary efficacy measure was the number of exacerbations, expressed as a rate over } \\
\text { the 24-week treatment period } \\
\text { SAE data described in paper only as "No deaths in the study and only a small proportion } \\
\text { of patients reported serious AEs" } \\
\text { SAE data obtained from sponsors website }\end{array}$ \\
\hline Notes & Sponsored by GSK \\
\hline
\end{tabular}

Risk of bias

\begin{tabular}{|c|c|c|}
\hline Bias & Authors' judgement & Support for judgement \\
\hline $\begin{array}{l}\text { Random sequence generation (selection } \\
\text { bias) }\end{array}$ & Low risk & $\begin{array}{l}\text { Patients were assigned to study treatment in } \\
\text { accordance with the randomisation sched- } \\
\text { ule from the Interactive Voice Recognition } \\
\text { System, which was part of the GSK System } \\
\text { for the Central Allocation of Medication }\end{array}$ \\
\hline Allocation concealment (selection bias) & Low risk & $\begin{array}{l}\text { Blinded study medication was packed and } \\
\text { supplied by GlaxoSmithKline (GSK). All } \\
\text { treatment packs contained both Diskus/ } \\
\text { Accuhaler and Turbuhaler devices (either } \\
\text { active Diskus/Accuhaler }+ \text { placebo Tur- } \\
\text { buhaler, or active Turbuhaler }+ \text { placebo } \\
\text { Diskus/Accuhaler) and looked identical }\end{array}$ \\
\hline $\begin{array}{l}\text { Blinding of participants and personnel } \\
\text { (performance bias) } \\
\text { All outcomes }\end{array}$ & Low risk & Double-blind, double-dummy \\
\hline $\begin{array}{l}\text { Blinding of outcome assessment (detection } \\
\text { bias) } \\
\text { All outcomes }\end{array}$ & Low risk & Double-blind, double-dummy \\
\hline $\begin{array}{l}\text { Incomplete outcome data (attrition bias) } \\
\text { All outcomes }\end{array}$ & Low risk & $1258 / 1397(90 \%)$ completed the study \\
\hline Selective reporting (reporting bias) & Low risk & SAE data found on website \\
\hline $\begin{array}{l}\text { Independent Outcome Assessment } \\
\text { Asthma-related serious adverse events }\end{array}$ & High risk & No independent outcome assessment \\
\hline
\end{tabular}




\begin{tabular}{|c|c|}
\hline Methods & $\begin{array}{l}\text { Study design: a randomised, double-blind, double-dummy, multicentre, parallel-group } \\
\text { study over } 24 \text { weeks from December } 2003 \text { to March } 2005 \text { at } 235 \text { centres in } 16 \text { countries. } \\
\text { Argentina (15), Australia (22), Bulgaria (9), Czech Republic (12), Great Britain (25), } \\
\text { Hungary (27), India (7), Malaysia (4), Mexico (15), the Netherlands (24), the Philippines } \\
\text { (8), Poland (29), South Korea (7), South Africa (26), Thailand (4), Vietnam (1). Run- } \\
\text { in } 2 \text { weeks }\end{array}$ \\
\hline Participants & $\begin{array}{l}\text { Population: } 3335 \text { adolescents and adults ( } 12 \text { to } 83 \text { ) years with persistent asthma } \\
\text { Baseline characteristics: mean age } 38 \text { years. } \mathrm{FEV}_{1} 73 \% \text { predicted. Concomitant inhaled } \\
\text { corticosteroids used by } 100 \% \text { of participants. Run-in on previous dose of ICS alone } \\
\text { (LABA discontinued in the } 47 \% \text { of participants taking it previously) } \\
\text { Inclusion criteria: outpatients aged } 12 \text { years or over with a diagnosis of asthma for at } \\
\text { least } 6 \text { months and using ICS for at least } 3 \text { months. } \mathrm{FEV}_{1} \% \text { predicted of } 50 \% \text { or greater, } \\
\text { bronchodilator reversibility by an increase of at least } 12 \% \text { in } \mathrm{FEV}_{1} \text { following terbutaline } \\
1 \mathrm{mg} \text { and at least } 1 \text { asthma exacerbation in the previous } 1 \text { to } 12 \text { months, using reliever } \\
\text { medication on at least } 5 \text { of the last } 7 \text { days of the } 2 \text {-week run-in } \\
\text { Combination therapy, if used, was discontinued and replaced with ICS alone, at least } 4 \\
\text { weeks prior to study start (screening visit) } \\
\text { Exclusion criteria: patients using systemic corticosteroids or with respiratory infections } \\
\text { affecting asthma control within } 30 \text { days of study entry were excluded }\end{array}$ \\
\hline Interventions & $\begin{array}{l}\text { 1. Salmeterol/fluticasone } 25 / 125 \mu \mathrm{g} \text { bd } \times 2 \mathrm{pMDI} \\
\text { 2. Formoterol/budesonide } 12 / 400 \mu \mathrm{g} \text { bd } \times 1 \text { DPI (reported as } 9 / 320 \text { delivered dose in } \\
\text { the paper) } \\
\text { 3. Single inhaler therapy arm not included in this review }\end{array}$ \\
\hline
\end{tabular}

Outcomes

The primary outcome variable was time to first severe asthma exacerbation, defined as deterioration in asthma leading to at least one of the following: - hospitalisation or emergency room treatment due to asthma, or oral corticosteroid treatment due to asthma for at least 3 days, as judged by the investigator

SAE data reported in the paper and asthma-related SAE data obtained from AstraZeneca (data on file). There was 1 death in the salmeterol/fluticasone group due to cardiac failure and 1 death in the single inhaler therapy group due to respiratory failure (arm is not included in this review)

Notes Sponsored by AstraZeneca

\section{Risk of bias}

\begin{tabular}{|c|c|c|}
\hline Bias & Authors' judgement & Support for judgement \\
\hline $\begin{array}{l}\text { Random sequence generation (selection } \\
\text { bias) }\end{array}$ & Low risk & $\begin{array}{l}\text { The randomisation schedule was com- } \\
\text { puter-generated at AstraZeneca Research } \\
\text { and Development, Charnwood, UK. } \\
\text { Within each centre, patients were ran- } \\
\text { domised strictly sequentially as they be- } \\
\text { came eligible }\end{array}$ \\
\hline
\end{tabular}


Kuna 2007 (Continued)

\begin{tabular}{|c|c|c|}
\hline Allocation concealment (selection bias) & Low risk & $\begin{array}{l}\text { Individual treatment codes and code en- } \\
\text { velopes (indicating the treatment alloca- } \\
\text { tion for each randomised patient) were } \\
\text { provided, but code envelopes were to be } \\
\text { opened only in case of medical emergen- } \\
\text { cies }\end{array}$ \\
\hline $\begin{array}{l}\text { Blinding of participants and personnel } \\
\text { (performance bias) } \\
\text { All outcomes }\end{array}$ & Low risk & Double-blind, double-dummy \\
\hline $\begin{array}{l}\text { Blinding of outcome assessment (detection } \\
\text { bias) } \\
\text { All outcomes }\end{array}$ & Low risk & Double-blind, double-dummy \\
\hline $\begin{array}{l}\text { Incomplete outcome data (attrition bias) } \\
\text { All outcomes }\end{array}$ & Low risk & $3172 / 3335(95 \%)$ completed the study \\
\hline Selective reporting (reporting bias) & Low risk & $\begin{array}{l}\text { SAE data obtained from paper and spon- } \\
\text { sors }\end{array}$ \\
\hline $\begin{array}{l}\text { Independent Outcome Assessment } \\
\text { Asthma-related serious adverse events }\end{array}$ & High risk & No independent outcome assessment \\
\hline
\end{tabular}

Maspero 2010

Methods

Participants
Study design: this was a 52-week, randomised, multicentre, parallel-group, open-label, evaluator-blinded study conducted at 27 clinical sites in South America

Population: 404 adults (> 12 years of age) with persistent asthma

Baseline characteristics: mean age 36 years, $\mathrm{FEV}_{1} 77 \%$ predicted, all had received ICS (with or without LABA) for at least 12 weeks

Inclusion criteria: patients included in the study were 12 years or older, diagnosed with persistent asthma of $\geq 12$ months, had a forced expiratory volume in 1 second $\left(\mathrm{FEV}_{1}\right) \geq 50 \%$ predicted values, received medium- or high-dose ICS with or without LABA for $\geq 12$ weeks before screening, and were on a stable regimen for $>=2$ weeks before screening. Additional inclusion criteria were evidence of $\beta 2$-reversibility (increase in $\mathrm{FEV}_{1}$ of $\geq 12 \%$ and $\geq 200 \mathrm{~mL}$ within 10 to 15 minutes of SABA use); normal electrocardiogram (ECG), clinical laboratory tests, and chest radiograph; and adequate contraceptive precautions for women of childbearing age

Exclusion criteria: patients were excluded if they demonstrated a change $>20 \%$ in $\mathrm{FEV}_{1}$; required use of $>12$ inhalations of

SABA or two nebulised treatments with $2.5 \mathrm{mg}$ salbutamol on 2 consecutive days at any time between the screening and baseline visits; experienced a clinically judged deterioration (deterioration resulting in emergency treatment, hospitalisation, or treatment with additional asthma medication other than SABA); had intraocular pressure $\geq 22 \mathrm{mmHg}$ in either eye, glaucoma or evidence of cataract(s) at screening; was a current smoker (had smoked within the previous year) or ex-smoker (> 10 pack-years); received emergency

Regular treatment with formoterol and an inhaled corticosteroid versus regular treatment with salmeterol and an inhaled corticosteroid 29 


\begin{tabular}{l|l} 
& $\begin{array}{l}\text { treatment for airway obstruction in the past } 3 \text { months; or suffered a respiratory infection } \\
\text { within } 2 \text { weeks before screening }\end{array}$ \\
\hline Interventions & $\begin{array}{l}\text { 1. Mometasone/formoterol } 100 / 5(\mathrm{n}=141) \text { or } 200 / 5(\mathrm{n}=130) \mu \mathrm{g} 2 \text { puffs twice daily } \\
\text { 2. Fluticasone/salmeterol } 125 / 25(\mathrm{n}=68) \text { or } 250 / 25(\mathrm{n}=65) \mu \mathrm{g} 2 \text { puffs twice daily } \\
\text { Delivered by MDI and spacers were not permitted. Dose allocated according to previous } \\
\text { ICS use of the participant }\end{array}$ \\
\hline Outcomes & Primary outcome: adverse events \\
\hline Notes & $\begin{array}{l}\text { Sponsored by Merck and Co. Two deaths occurred (electrocution and gastric cancer) } \\
\text { and these were both in mometasone/formoterol } 200 / 10 \text { group (see FDA report at www. } \\
\text { fda.gov/downloads/Drugs/.../UCM224593.pdf }\end{array}$ \\
\hline
\end{tabular}

\section{Risk of bias}

\begin{tabular}{|c|c|c|}
\hline Bias & Authors' judgement & Support for judgement \\
\hline $\begin{array}{l}\text { Random sequence generation (selection } \\
\text { bias) }\end{array}$ & Unclear risk & No details \\
\hline Allocation concealment (selection bias) & Unclear risk & No details \\
\hline $\begin{array}{l}\text { Blinding of participants and personnel } \\
\text { (performance bias) } \\
\text { All outcomes }\end{array}$ & High risk & Open label \\
\hline $\begin{array}{l}\text { Blinding of outcome assessment (detection } \\
\text { bias) } \\
\text { All outcomes }\end{array}$ & Low risk & Evaluator blinded \\
\hline $\begin{array}{l}\text { Incomplete outcome data (attrition bias) } \\
\text { All outcomes }\end{array}$ & Low risk & Over $80 \%$ completed study in each arm \\
\hline Selective reporting (reporting bias) & Unclear risk & $\begin{array}{l}\text { Mortality details obtained from FDA re- } \\
\text { port }\end{array}$ \\
\hline $\begin{array}{l}\text { Independent Outcome Assessment } \\
\text { Asthma-related serious adverse events }\end{array}$ & High risk & Not reported \\
\hline
\end{tabular}

\section{Papi 2007}

Methods

Study design: a randomised, double-blind, multicentre, parallel-group study over 12 weeks from November 2004 to June 2005 at 12 outpatient respiratory clinics in Europe (Poland (6) Ukraine (6)). Run-in 2 weeks

Participants

Population: 228 adults (18 to 65) years with moderate to severe persistent asthma. Baseline characteristics: mean age 48 years. FEV $_{1}$ 67\% predicted. Concomitant in- 


\begin{tabular}{|c|c|}
\hline & $\begin{array}{l}\text { haled corticosteroids used by } 100 \% \text { of participants. Average ICS dose } 731 \mu \mathrm{g} / \text { day (BDP } \\
\text { equivalent). Run in on ICS alone (no other anti-asthma medication permitted) } \\
\text { Inclusion criteria: clinical diagnosis of moderate to severe persistent asthma for at least } \\
6 \text { months, } \mathrm{FEV}_{1} \% \text { predicted between } 50 \% \text { to } 80 \% \text {, bronchodilator reversibility by an } \\
\text { increase of at least } 12 \% \text { in } \mathrm{FEV}_{1} \text { (or, alternatively, of } 200 \mathrm{ml} \text { ) over baseline measured } 30 \\
\text { min after } 2 \text { puffs }(2 \times 100 \mu \mathrm{g} \text { ) of inhaled salbutamol administered via pMDI. Treated with } \\
\text { ICS at a daily dose of less than } 1000 \mu \mathrm{g} \text { of BDP-equivalent and had asthma symptoms } \\
\text { not adequately controlled as defined by: presence of daily symptoms at least once a week, } \\
\text { night-time symptoms at least twice a month and daily use of short-acting beta2-agonists. } \\
\text { Exclusion criteria: COPD, current or ex-smokers (more than } 10 \text { pack-years); severe } \\
\text { asthma exacerbation or symptomatic infection of the airways in the previous } 8 \text { weeks; } \\
\text { more than } 3 \text { courses of oral corticosteroids or hospitalisation due to asthma in the previous } \\
6 \text { months; treatment with LABAs, anticholinergics or antihistamines in the previous } 2 \\
\text { weeks, and/or with topical or intranasal corticosteroids and leukotriene antagonists in } \\
\text { the previous } 4 \text { weeks, change of ICS dose in the previous } 4 \text { weeks }\end{array}$ \\
\hline Interventions & $\begin{array}{l}\text { 1. Beclomethasone/formoterol } 100 / 6 \mu \mathrm{g} \times 2 \text { bd } \\
\text { 2. Fluticasone/salmeterol } 125 / 25 \mu \mathrm{g} \text { x } 2 \text { bd } \\
\text { Delivery was via pMDI }\end{array}$ \\
\hline Outcomes & $\begin{array}{l}\text { The primary outcome variable was morning predose PEF measured by patients in the } \\
\text { last } 2 \text { weeks of treatment period (weeks } 11 \text { and 12). No serious adverse events reported in } \\
\text { either arm of the trial and the absence of deaths and hospitalisations has been confirmed } \\
\text { by Chiesi; no details of one of the patients withdrawn due to "Development of an } \\
\text { exclusion criteria" }\end{array}$ \\
\hline Notes & Sponsored by Chiesi \\
\hline
\end{tabular}

\section{Risk of bias}

\begin{tabular}{ll|l}
\hline Bias & Authors' judgement & Support for judgement \\
\hline $\begin{array}{l}\text { Random sequence generation (selection } \\
\text { bias) }\end{array}$ & Low risk & $\begin{array}{l}\text { Randomisation was in balanced-block de- } \\
\text { sign stratified by centres }\end{array}$ \\
\hline Allocation concealment (selection bias) & Low risk & $\begin{array}{l}\text { "Each patient was identified with a ran- } \\
\text { domisation number, from 001 to 260 (in } \\
\text { blocks of four); each investigator assigned } \\
\text { the lowest available randomisation number } \\
\text { at each site." }\end{array}$ \\
\hline
\end{tabular}

Blinding of participants and personnel Low risk (performance bias)

All outcomes

Blinding of outcome assessment (detection Low risk bias)

All outcomes
Described as double-blind but not doubledummy and inhalers were different shape and size but this was "masked" using a nonremovable external covering for the inhalers

Described as double-blind but not doubledummy and inhalers were different shape and size but this was "masked" using a non-

Regular treatment with formoterol and an inhaled corticosteroid versus regular treatment with salmeterol and an inhaled corticosteroid $3 \mathrm{I}$ 
Papi 2007 (Continued)

removable external covering for the inhalers

\begin{tabular}{|c|c|c|}
\hline $\begin{array}{l}\text { Incomplete outcome data (attrition bias) } \\
\text { All outcomes }\end{array}$ & Low risk & $225 / 228(99 \%)$ completed the study \\
\hline Selective reporting (reporting bias) & Low risk & $\begin{array}{l}\text { "During the study no deaths or hospital- } \\
\text { izations occurred." Data on file at Chiesi }\end{array}$ \\
\hline $\begin{array}{l}\text { Independent Outcome Assessment } \\
\text { Asthma-related serious adverse events }\end{array}$ & High risk & No independent outcome assessment \\
\hline
\end{tabular}

Ringdal 2002

Methods

Participants
Study design: a randomised, double-blind, double-dummy, multicentre, parallel-group study over 12 weeks from May 1998 to June 1999 at 52 primary care practices and hospital respiratory units in 11 countries (Austria (4), Belgium(4), Croatia (2), Denmark (4), Finland (2), Germany (7), Italy (3), Norway (5), Russia (2), Slovakia (3), United Kingdom (16)). Run-in 2 weeks

Population: 428 adolescents and adults (16 to 75$)$ years with moderate-to-severe asthma who were uncontrolled on existing corticosteroid therapy

Baseline characteristics: mean age 47 years. FEV $_{1} 69 \%$ predicted. Concomitant inhaled corticosteroids used by $100 \%$ of participants. Run-in on previous dose of ICS (no LABA allowed in previous 2 weeks before recruitment).

Inclusion criteria: aged 16 to 75 years with a documented clinical history of asthma currently receiving 1000 to $1600 \mu \mathrm{g} /$ day of budesonide, beclomethasone dipropionate or flunisolide, or 500 to $800 \mu \mathrm{g} /$ day fluticasone propionate, for at least 4 weeks before Visit 1

At the end of run-in, $\mathrm{FEV}_{1} \%$ predicted of $50 \%$ to $85 \%$ at any of Visits 1 or $2 / 2 \mathrm{~A}$ (bronchodilators withheld for 6 hours), bronchodilator reversibility by an increase of at least $15 \%$ in $\mathrm{FEV}_{1}$ over baseline 15 minutes after inhaling $400 \mu \mathrm{g}$ of salbutamol at Visit 1 or $2 / 2 \mathrm{~A}$, and a symptom score (day and night combined) of at least 2 or relief bronchodilator use on at least 2 separate occasions (any dose) per day on at least 4 of the last 7 days of the run-in period

Exclusion criteria: a smoking history of 10 pack-years or more, an asthma exacerbation or upper or lower respiratory tract infection within the previous month, systemic or nasal steroids or anti leukotrienes within the previous 4 weeks, or long-acting/oral/slowrelease beta 2 -agonists in the previous 2 weeks before Visit 1
1. Salmeterol/fluticasone $50 / 250 \mu \mathrm{g}$ bd via Diskus

2. Formoterol $(12 \mu \mathrm{g} b \mathrm{~d})+$ budesonide $(800 \mu \mathrm{g}$ bd $)$ via separate turbohalers
Outcomes

Notes
The primary efficacy measure was mean $\mathrm{PEF}_{a m}$ over the week prior to the end of treatment (Week 12)

SAE data obtained from sponsor's website and also reported in the paper publication 
Ringdal 2002 (Continued)

\section{Risk of bias}

\begin{tabular}{l|l|l}
\hline Bias & Authors' judgement & Support for judgement \\
\hline $\begin{array}{l}\text { Random sequence generation (selection } \\
\text { bias) }\end{array}$ & Low risk & $\begin{array}{l}\text { A randomisation code was generated us- } \\
\text { ing the Glaxo Wellcome computer pro- } \\
\text { gram 'Patient Allocation for Clinical Trials' } \\
\text { (block size of 4) and non-overlapping sets of } \\
\text { treatment numbers were allocated to each } \\
\text { centre. Treatment numbers were allocated } \\
\text { at Visit 2 in consecutive order, starting with } \\
\text { the lowest number available at that centre }\end{array}$ \\
\hline Allocation concealment (selection bias) & Low risk & $\begin{array}{l}\text { Numbered treatment packs of study drugs } \\
\text { were labelled to ensure that both patients } \\
\text { and investigators were blinded to the treat- } \\
\text { ment allocation, and the randomisation } \\
\text { codes were not revealed to investigators or } \\
\text { other study participants until after recruit- } \\
\text { ment, treatment, data collection and anal- } \\
\text { yses were complete }\end{array}$ \\
\hline
\end{tabular}

Blinding of participants and personnel Low risk (performance bias)

Double-blind, double-dummy

All outcomes

Blinding of outcome assessment (detection Low risk bias)

Double-blind, double-dummy

All outcomes

Incomplete outcome data (attrition bias) Low risk

$379 / 428$ (89\%) completed the study

All outcomes

\begin{tabular}{l|l|l}
\hline Selective reporting (reporting bias) & Low risk & $\begin{array}{l}\text { SAE reported in paper and on sponsor's } \\
\text { trial report }\end{array}$ \\
\hline $\begin{array}{l}\text { Independent Outcome Assessment } \\
\text { Asthma-related serious adverse events }\end{array}$ & High risk & No independent outcome assessment \\
\hline
\end{tabular}

\section{SAM 40010}

Methods

Study design: a randomised, double-blind, double-dummy, multicentre, parallel-group study over 12 weeks from January 2000 to July 2000 at 50 centres in Europe (Belgium, Denmark, Germany, Ireland, Poland and The Netherlands). Run-in 2 to 4 weeks

Participants

Population: 373 adolescents and adults with asthma that is poorly controlled by low doses of inhaled corticosteroid

Baseline characteristics: mean age 42 years. Concomitant inhaled corticosteroids used

Regular treatment with formoterol and an inhaled corticosteroid versus regular treatment with salmeterol and an inhaled corticosteroid 33 


by $100 \%$ of participants. No details of treatment given during run-in
Inclusion criteria: aged 12 years and older with reversible airways obstruction who re-
mained symptomatic with inhaled corticosteroid treatment ( 400 to $500 \mu \mathrm{gg} / \mathrm{day}$ budes-
onide or equivalent), for at least 4 weeks prior to Visit 1 (start of the run-in period),
had a clinical history of asthma with symptoms including cough, wheeze and shortness
of breath requiring treatment with short-acting beta 2 -agonist for a period of at least 6
months, a mean morning PEF during the last 7 consecutive days of the run-in period of
between $50 \%$ and $85 \%$ of their PEF measured 15 minutes after administration of 400
$\mu g$ of salbutamol at Visit 1 , and had recorded a cumulative total symptom score (daytime
plus night-time) of at least 8 for the last 7 consecutive days of the run-in period
Exclusion criteria: not reported

\begin{tabular}{|l|l|}
\hline Interventions & 1. Salmeterol/fluticasone $50 / 100 \mu \mathrm{g}$ bd via Diskus \\
2. Budesonide $200 \mu \mathrm{g}$ bd + formoterol $6 \mu \mathrm{g}$ bd via DPI
\end{tabular}

\begin{tabular}{ll} 
Outcomes & $\begin{array}{l}\text { The primary study endpoint was morning peak expiratory flow, assessed as the mean of } \\
\text { the morning PEF values recorded during the 12-week treatment period. SAE data avail- } \\
\text { able from web report. One death in formoterol/budesonide group due to gastrointestinal } \\
\text { obstruction, cardiac failure and septic shock }\end{array}$ \\
\hline Notes & Sponsored by GSK \\
\hline
\end{tabular}

\section{Risk of bias}

\begin{tabular}{|c|c|c|}
\hline Bias & Authors' judgement & Support for judgement \\
\hline $\begin{array}{l}\text { Random sequence generation (selection } \\
\text { bias) }\end{array}$ & Low risk & $\begin{array}{l}\text { Randomisation code was computer-gener- } \\
\text { ated using Patient Allocation for Clinical } \\
\text { Trials developed by GlaxoSmithKline re- } \\
\text { search and development }\end{array}$ \\
\hline
\end{tabular}

Allocation concealment (selection bias) Low risk

Treatment numbers were assigned sequentially to all eligible subjects starting with the lowest number available to the investigator

Blinding of participants and personnel Low risk Double-blind, double-dummy (performance bias)

All outcomes

Blinding of outcome assessment (detection Low risk

Double-blind, double-dummy bias)

All outcomes

\begin{tabular}{|c|c|c|}
\hline $\begin{array}{l}\text { Incomplete outcome data (attrition bias) } \\
\text { All outcomes }\end{array}$ & Low risk & $362 / 373(97 \%)$ completed the study \\
\hline
\end{tabular}

\begin{tabular}{lll}
\hline Selective reporting (reporting bias) & Low risk & SAE data presented in web report
\end{tabular}




\section{SAM 40048}

Methods

\begin{tabular}{|c|c|}
\hline & $\begin{array}{l}\text { study over } 12 \text { weeks from August } 2001 \text { to September } 2002 \text { at } 27 \text { centres in Germany. } \\
\text { Run-in } 2 \text { weeks }\end{array}$ \\
\hline Participants & $\begin{array}{l}\text { Population: } 248 \text { adults with moderate bronchial asthma. } \\
\text { Baseline characteristics: mean age } 48 \text { years. } \mathrm{FEV}_{1} 65 \% \text { predicted (at Visit } 2 \text { (baseline) } \\
\text { ). Concomitant inhaled corticosteroids used by } 100 \% \text { of participants. No details of } \\
\text { treatment given during run-in } \\
\text { Inclusion criteria: aged } 18 \text { years and older with moderate asthma. } \mathrm{FEV}_{1} \% \text { predicted } \\
\text { between } 50 \% \text { to } 80 \% \text {, bronchodilator reversibility by an increase of at least } 15 \% \text { in } \\
\mathrm{FEV}_{1} \text {, inhaled corticosteroid (ICS) treatment } 1000 \mu \mathrm{g} \text { beclomethasone dipropionate } \\
(\mathrm{BDP}) / \text { day or equivalent; and symptomatic asthma } \\
\text { Exclusion criteria: exacerbations or emergency visits during the } 4 \text {-week pre-study period } \\
\text { and smoking (more than } 20 \text { cigarettes per day) }\end{array}$ \\
\hline Interventions & $\begin{array}{l}\text { 1. Salmeterol/fluticasone } 50 / 250 \mu \mathrm{g} \text { bd via Diskus } \\
\text { 2. Formoterol/budesonide } 6 / 200 \mu \mathrm{g} \text { bd via DPI }\end{array}$ \\
\hline Outcomes & $\begin{array}{l}\text { The primary variable was the change in forced expiratory volume in } 1 \text { second }\left(\mathrm{FEV}_{1}\right) \\
\text { (\% predicted), after } 12 \text { weeks of treatment compared to baseline } \\
\text { SAE data in web report }\end{array}$ \\
\hline Notes & Sponsored by GSK \\
\hline
\end{tabular}

\section{Risk of bias}

\section{Bias}

Authors' judgement

Random sequence generation (selection Low risk bias)

Allocation concealment (selection bias) Low risk
Support for judgement

"The allocation of patients to the two treatment groups was undertaken according to a predetermined randomisation schedule (in a ratio of 1 to 1)." GSK data on file

"The allocation was undertaken as a block randomisation, with identical allocation ratios in each study centre. Every investigator had to allocate the patient to the lowest available number at visit 2 . Adherence to this randomisation schedule was checked during the process of data management." 


\begin{tabular}{|c|c|c|}
\hline $\begin{array}{l}\text { Blinding of participants and personnel } \\
\text { (performance bias) } \\
\text { All outcomes }\end{array}$ & Low risk & Double-blind, double-dummy \\
\hline $\begin{array}{l}\text { Blinding of outcome assessment (detection } \\
\text { bias) } \\
\text { All outcomes }\end{array}$ & Low risk & Double-blind, double-dummy \\
\hline $\begin{array}{l}\text { Incomplete outcome data (attrition bias) } \\
\text { All outcomes }\end{array}$ & Low risk & $235 / 248(95 \%)$ completed the study \\
\hline Selective reporting (reporting bias) & Low risk & SAE data in web report \\
\hline $\begin{array}{l}\text { Independent Outcome Assessment } \\
\text { Asthma-related serious adverse events }\end{array}$ & High risk & No independent outcome assessment \\
\hline
\end{tabular}

AMD: adjustable maintenance dosing

BDF: budesonide

DPI: dry powder inhaler

COPD: chronic obstructive pulmonary disease

FDA: Food and Drug Administration

FEV1: forced expiratory volume in one second

FPS: fluticasone propionate and salmeterol inhaler

GCS: glucocorticosteroid

GSK: GlaxoSmithKline

IVRS: Interactive voice recording system

LABA: long-acting beta ${ }_{2}$-agonist

PEF: peak expiratory flow

pMDI: pressurised metered-dose inhaler

SABA: short-acting beta 2 -agonist

SAE: serious adverse event

Characteristics of excluded studies [ordered by study ID]

\begin{tabular}{ll}
\hline Study & Reason for exclusion \\
\hline Bleecker 2008 & Review of 2 other studies (Busse 2008; Kuna 2007) \\
\hline Dhillon 2006 & Review of studies on BDP/formoterol \\
\hline Hampel 2008 & Single-dose study \\
\hline Jung 2008 & Fluticasone/salmeterol versus current care \\
\hline Lee 2003 & 4-week cross-over study \\
\hline
\end{tabular}

Regular treatment with formoterol and an inhaled corticosteroid versus regular treatment with salmeterol and an inhaled corticosteroid 36 for chronic asthma: serious adverse events (Review)

Copyright (? 201 I The Cochrane Collaboration. Published by John Wiley \& Sons, Ltd. 


\section{(Continued)}

Lyseng-Williamson 2003 Pharmacoeconomic review of studies on fluticasone/salmeterol inhaler

BDP: beclometasone

Regular treatment with formoterol and an inhaled corticosteroid versus regular treatment with salmeterol and an inhaled corticosteroid 37 for chronic asthma: serious adverse events (Review)

Copyright (? 201 I The Cochrane Collaboration. Published by John Wiley \& Sons, Ltd. 
DATA AND ANALYSES

\section{Comparison 1. Fixed-dose formoterol/ICS versus salmeterol/fluticasone}

\begin{tabular}{|c|c|c|c|c|}
\hline Outcome or subgroup title & $\begin{array}{l}\text { No. of } \\
\text { studies }\end{array}$ & $\begin{array}{c}\text { No. of } \\
\text { participants }\end{array}$ & Statistical method & Effect size \\
\hline 1 All-cause mortality & 10 & & Peto Odds Ratio (Peto, Fixed, 95\% CI) & Subtotals only \\
\hline $\begin{array}{l}1.1 \text { Formoterol/budesonide vs } \\
\text { salmeterol/fluticasone }\end{array}$ & 7 & 5935 & Peto Odds Ratio (Peto, Fixed, 95\% CI) & $1.03[0.06,16.44]$ \\
\hline $\begin{array}{l}1.2 \\
\text { Formoterol/beclomethasone vs } \\
\text { salmeterol/fluticasone }\end{array}$ & 1 & 228 & Peto Odds Ratio (Peto, Fixed, 95\% CI) & $0.0[0.0,0.0]$ \\
\hline $\begin{array}{l}1.3 \text { Formoterol/mometasone } \\
\text { vs salmeterol/fluticasone }\end{array}$ & 1 & 404 & Peto Odds Ratio (Peto, Fixed, 95\% CI) & $4.46[0.23,85.40]$ \\
\hline $\begin{array}{l}1.4 \text { Formoterol/fluticasone vs } \\
\text { salmeterol/fluticasone }\end{array}$ & 1 & 202 & Peto Odds Ratio (Peto, Fixed, 95\% CI) & $7.39[0.15,372.38]$ \\
\hline $\begin{array}{l}2 \text { All-cause non-fatal serious } \\
\text { adverse events }\end{array}$ & 10 & & Peto Odds Ratio (Peto, Fixed, 95\% CI) & Subtotals only \\
\hline $\begin{array}{l}2.1 \text { Formoterol/budesonide vs } \\
\text { salmeterol/fluticasone }\end{array}$ & 7 & 5935 & Peto Odds Ratio (Peto, Fixed, 95\% CI) & $1.14[0.82,1.59]$ \\
\hline $\begin{array}{l}2.2 \\
\text { Formoterol/beclomethasone vs } \\
\text { salmeterol/fluticasone }\end{array}$ & 1 & 228 & Peto Odds Ratio (Peto, Fixed, 95\% CI) & $0.0[0.0,0.0]$ \\
\hline $\begin{array}{l}2.3 \text { Formoterol/mometasone } \\
\text { vs salmeterol/Aluticasone }\end{array}$ & 1 & 404 & Peto Odds Ratio (Peto, Fixed, 95\% CI) & $1.07[0.40,2.84]$ \\
\hline $\begin{array}{l}\text { 2.4 Formoterol/fluticasone vs } \\
\text { salmeterol/fluticasone }\end{array}$ & 1 & 202 & Peto Odds Ratio (Peto, Fixed, 95\% CI) & $0.14[0.00,6.82]$ \\
\hline $\begin{array}{l}3 \text { Asthma related non-fatal serious } \\
\text { adverse events }\end{array}$ & 8 & & Peto Odds Ratio (Peto, Fixed, 95\% CI) & Subtotals only \\
\hline $\begin{array}{l}\text { 3.1 Formoterol/budesonide vs } \\
\text { salmeterol/fluticasone }\end{array}$ & 7 & 5935 & Peto Odds Ratio (Peto, Fixed, 95\% CI) & $0.69[0.37,1.26]$ \\
\hline $\begin{array}{l}3.2 \\
\text { Formoterol/beclomethasone vs } \\
\text { salmeterol/fluticasone }\end{array}$ & 1 & 228 & Peto Odds Ratio (Peto, Fixed, 95\% CI) & $0.0[0.0,0.0]$ \\
\hline $\begin{array}{l}4 \text { All-cause mortality (risk } \\
\text { difference) }\end{array}$ & 10 & & Risk Difference (M-H, Fixed, 95\% CI) & Subtotals only \\
\hline $\begin{array}{l}\text { 4.1 Formoterol/budesonide vs } \\
\text { salmeterol/fluticasone }\end{array}$ & 7 & 5935 & Risk Difference (M-H, Fixed, 95\% CI) & $9.36[-0.00,0.00]$ \\
\hline $\begin{array}{l}4.2 \\
\text { Formoterol/beclomethasone vs } \\
\text { salmeterol/fluticasone }\end{array}$ & 1 & 228 & Risk Difference (M-H, Fixed, 95\% CI) & $0.0[-0.02,0.02]$ \\
\hline $\begin{array}{l}\text { 4.3 Formoterol/mometasone } \\
\text { vs salmeterol/fluticasone }\end{array}$ & 1 & 404 & Risk Difference (M-H, Fixed, 95\% CI) & $0.01[-0.01,0.02]$ \\
\hline $\begin{array}{l}\text { 4.4 Formoterol/fluticasone vs } \\
\text { salmeterol/fluticasone }\end{array}$ & 1 & 202 & Risk Difference (M-H, Fixed, 95\% CI) & $0.01[-0.02,0.04]$ \\
\hline $\begin{array}{l}5 \text { All-cause non-fatal serious } \\
\text { adverse events (risk difference) }\end{array}$ & 10 & & Risk Difference (M-H, Fixed, 95\% CI) & Subtotals only \\
\hline
\end{tabular}

Regular treatment with formoterol and an inhaled corticosteroid versus regular treatment with salmeterol and an inhaled corticosteroid 38 for chronic asthma: serious adverse events (Review)

Copyright ( 201 I The Cochrane Collaboration. Published by John Wiley \& Sons, Ltd. 


\begin{tabular}{|c|c|c|c|c|}
\hline $\begin{array}{l}5.1 \text { Formoterol/budesonide vs } \\
\text { salmeterol/fluticasone }\end{array}$ & 7 & 5935 & Risk Difference (M-H, Fixed, 95\% CI) & $0.00[-0.00,0.01]$ \\
\hline $\begin{array}{l}5.2 \\
\text { Formoterol/beclomethasone vs } \\
\text { salmeterol/fluticasone }\end{array}$ & 1 & 228 & Risk Difference (M-H, Fixed, 95\% CI) & $0.0[-0.02,0.02]$ \\
\hline $\begin{array}{l}5.3 \text { Formoterol/mometasone } \\
\text { vs salmeterol/fluticasone }\end{array}$ & 1 & 404 & Risk Difference (M-H, Fixed, 95\% CI) & $0.00[-0.04,0.05]$ \\
\hline $\begin{array}{l}5.4 \text { Formoterol/fluticasone vs } \\
\text { salmeterol/fluticasone }\end{array}$ & 1 & 202 & Risk Difference (M-H, Fixed, 95\% CI) & $-0.01[-0.04,0.02]$ \\
\hline $\begin{array}{l}\text { Asthma-related non-fatal serious } \\
\text { adverse events (risk difference) }\end{array}$ & 8 & & Risk Difference (M-H, Fixed, 95\% CI) & Subtotals only \\
\hline $\begin{array}{l}\text { 6.1 Formoterol/budesonide vs } \\
\text { salmeterol/Aluticasone }\end{array}$ & 7 & 5935 & Risk Difference (M-H, Fixed, 95\% CI) & $-0.00[-0.01,0.00]$ \\
\hline 6.2 & 1 & 228 & Risk Difference (M-H, Fixed, 95\% CI) & $0.0[-0.02,0.02]$ \\
\hline
\end{tabular}

\section{Analysis I.I. Comparison I Fixed-dose formoterol/ICS versus salmeterol/fluticasone, Outcome I All-cause mortality.}

Review: Regular treatment with formoterol and an inhaled corticosteroid versus regular treatment with salmeterol and an inhaled corticosteroid for chronic asthma: serious adverse events

Comparison: I Fixed-dose formoterol//CS versus salmeterol/fluticasone

Outcome: I All-cause mortality

\begin{tabular}{|c|c|c|c|c|}
\hline \multirow[t]{2}{*}{ Study or subgroup } & \multirow{2}{*}{$\begin{array}{r}\text { Formoterol/ICS } \\
n / N\end{array}$} & \multicolumn{2}{|r|}{$\begin{array}{r}\text { Peto } \\
\text { Odds Ratio }\end{array}$} & \multirow{2}{*}{$\begin{array}{r}\text { Peto } \\
\text { Odds Ratio } \\
\text { Peto,Fixed,95\% Cl }\end{array}$} \\
\hline & & $n / N$ & Peto,Fixed,95\% Cl & \\
\hline \multicolumn{5}{|c|}{ | Formoterol/budesonide vs salmeterol/fluticasone } \\
\hline Busse 2008 & $0 / 427$ & $0 / 406$ & & $0.0[0.0,0.0]$ \\
\hline Dahl 2006 & 0/700 & 0/697 & & $0.0[0.0,0.0]$ \\
\hline Ringdal 2002 & $0 / 216$ & $0 / 212$ & & $0.0[0.0,0.0]$ \\
\hline Aalbers 2004 & $0 / 215$ & $0 / 224$ & & $0.0[0.0,0.0]$ \\
\hline SAM 40048 & $0 / 126$ & $0 / 121$ & & $0.0[0.0,0.0]$ \\
\hline SAM 40010 & $1 / 183$ & $0 / 190$ & & $7.68[0.15,387.17]$ \\
\hline Kuna 2007 & 0/1099 & $1 / 1119$ & & $0.14[0.00,6.94]$ \\
\hline Subtotal (95\% CI) & 2966 & 2969 & & $1.03[0.06,16.44]$ \\
\hline \multicolumn{5}{|c|}{ Total events: I (Formoterol//ICS), I (Salmeterol/Fluticasone) } \\
\hline \multicolumn{5}{|c|}{ Heterogeneity: $\mathrm{Ch}^{2}=2.02, \mathrm{df}=\mathrm{I}(P=0.16) ; \mathrm{I}^{2}=50 \%$} \\
\hline \multicolumn{5}{|c|}{ Test for overall effect: $Z=0.02(P=0.98)$} \\
\hline & & & $\begin{array}{llll}0.1 & 1 & 10 & 100\end{array}$ & \\
\hline & & Favours $\mathrm{F}$ & Favours Sal & (Continued. \\
\hline
\end{tabular}

Regular treatment with formoterol and an inhaled corticosteroid versus regular treatment with salmeterol and an inhaled corticosteroid 39 for chronic asthma: serious adverse events (Review) 


\begin{tabular}{|c|c|c|c|c|}
\hline \multirow[t]{2}{*}{ Study or subgroup } & $\begin{array}{r}\text { Formoterol/ICS } \\
n / N\end{array}$ & \multicolumn{2}{|r|}{$\begin{array}{r}\text { Peto } \\
\text { Odds Ratio }\end{array}$} & $\begin{array}{r}(\ldots \text { Continued }) \\
\text { Peto } \\
\text { Odds Ratio } \\
\text { Peto,Fixed,95\% Cl }\end{array}$ \\
\hline & $\mathrm{n} / \mathrm{N}$ & $\mathrm{n} / \mathrm{N}$ & Peto,Fixed,95\% Cl & Peto,Fixed,95\% Cl \\
\hline \multicolumn{5}{|c|}{2 Formoterol/beclomethasone vs salmeterol/fluticasone } \\
\hline Papi 2007 & $0 / 115$ & $0 / 113$ & & $0.0[0.0,0.0]$ \\
\hline Subtotal $(95 \% \mathrm{CI})$ & 115 & 113 & & $0.0[0.0,0.0]$ \\
\hline \multicolumn{5}{|c|}{ Total events: 0 (Formoterol//CS), 0 (Salmeterol/Fluticasone) } \\
\hline \multicolumn{5}{|l|}{ Heterogeneity: not applicable } \\
\hline \multicolumn{5}{|c|}{ Test for overall effect: $Z=0.0(P<0.0000 \mathrm{I})$} \\
\hline \multicolumn{5}{|c|}{3 Formoterol/mometasone vs salmeterol/fluticasone } \\
\hline Maspero 2010 & $2 / 271$ & $0 / 133$ & + & $4.46[0.23,85.40]$ \\
\hline Subtotal $(95 \% \mathrm{CI})$ & 271 & 133 & & $4.46[0.23,85.40]$ \\
\hline \multicolumn{5}{|c|}{ Total events: 2 (Formoterol/ICS), 0 (Salmeterol/Fluticasone) } \\
\hline \multicolumn{5}{|c|}{ Heterogeneity: not applicable } \\
\hline \multicolumn{5}{|c|}{ Test for overall effect: $Z=0.99(P=0.32)$} \\
\hline \multicolumn{5}{|c|}{4 Formoterol/fluticasone vs salmeterol/fluticasone } \\
\hline Bodzenta-Lukaszyk 201 I & $1 / 101$ & $0 / 101$ & & $7.39[0.15,372.38]$ \\
\hline Subtotal $(95 \% \mathrm{CI})$ & 101 & 101 & & $7.39[0.15,372.38]$ \\
\hline \multicolumn{5}{|c|}{ Total events: I (Formotero//ICS), 0 (Salmeterol/Fluticasone) } \\
\hline \multicolumn{5}{|c|}{ Heterogeneity: not applicable } \\
\hline \multicolumn{5}{|c|}{ Test for overall effect: $Z=1.00(P=0.32)$} \\
\hline Test for subgroup differences & $83, \mathrm{df}=2(\mathrm{P}=0.6$ & & & \\
\hline
\end{tabular}

Regular treatment with formoterol and an inhaled corticosteroid versus regular treatment with salmeterol and an inhaled corticosteroid 40 for chronic asthma: serious adverse events (Review)

Copyright ( 201 I The Cochrane Collaboration. Published by John Wiley \& Sons, Ltd. 


\section{Analysis I.2. Comparison I Fixed-dose formoterol/ICS versus salmeterol/fluticasone, Outcome 2 All-cause non-fatal serious adverse events.}

Review: Regular treatment with formoterol and an inhaled corticosteroid versus regular treatment with salmeterol and an inhaled corticosteroid for chronic asthma: serious adverse events

Comparison: I Fixed-dose formoterol/ICS versus salmeterol/fluticasone

Outcome: 2 All-cause non-fatal serious adverse events

\begin{tabular}{|c|c|c|c|c|}
\hline Study or subgroup & $\begin{array}{r}\text { Formoterol/ICS } \\
n / N\end{array}$ & $\begin{array}{l}\text { Salmeterol/Fluticasone } \\
\mathrm{n} / \mathrm{N}\end{array}$ & $\begin{array}{c}\text { Peto } \\
\text { Odds Ratio } \\
\text { Peto,Fixed,95\% Cl }\end{array}$ & $\begin{array}{r}\text { Peto } \\
\text { Odds Ratio } \\
\text { Peto,Fixed,95\% Cl }\end{array}$ \\
\hline \multicolumn{5}{|c|}{ | Formoterol/budesonide vs salmeterol/fluticasone } \\
\hline SAM 40048 & $1 / 126$ & $|/| 2 \mid$ & & $0.96[0.06,15.45]$ \\
\hline SAM 40010 & $2 / 183$ & $0 / 190$ & & $7.72[0.48,123.94]$ \\
\hline Ringdal 2002 & $3 / 216$ & $2 / 212$ & 7 & $1.47[0.25,8.55]$ \\
\hline Aalbers 2004 & $11 / 215$ & $5 / 224$ & - & $2.27[0.84,6.15]$ \\
\hline Busse 2008 & $10 / 427$ & $9 / 406$ & $\rightarrow$ & $1.06[0.43,2.63]$ \\
\hline Dahl 2006 & $11 / 700$ & 20/697 & - & $0.55[0.27,1.12]$ \\
\hline Kuna 2007 & $39 / 1099$ & $31 / 1119$ & P & $1.29[0.80,2.08]$ \\
\hline Subtotal (95\% CI) & 2966 & 2969 & 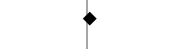 & $1.14[0.82,1.59]$ \\
\hline \multicolumn{5}{|c|}{ Total events: 77 (Formoterol//CS), 68 (Salmeterol/Fluticasone) } \\
\hline \multicolumn{5}{|c|}{ Heterogeneity: $\mathrm{Chi}^{2}=8.06, \mathrm{df}=6(P=0.23) ; \mathrm{I}^{2}=26 \%$} \\
\hline \multicolumn{5}{|c|}{ Test for overall effect: $Z=0.79(P=0.43)$} \\
\hline \multicolumn{5}{|c|}{2 Formoterol/beclomethasone vs salmeterol/fluticasone } \\
\hline Papi 2007 & $0 / 115$ & $0 / 113$ & & $0.0[0.0,0.0]$ \\
\hline Subtotal (95\% CI) & 115 & 113 & & $0.0[0.0,0.0]$ \\
\hline \multicolumn{5}{|c|}{ Total events: 0 (Formoterol//ICS), 0 (Salmeterol/Fluticasone) } \\
\hline \multicolumn{5}{|c|}{ Heterogeneity: not applicable } \\
\hline \multicolumn{5}{|c|}{ Test for overall effect: $Z=0.0(P<0.0000 \mathrm{I})$} \\
\hline \multicolumn{5}{|c|}{3 Formoterol/mometasone vs salmeterol/fluticasone } \\
\hline Maspero 2010 & $|3 / 27|$ & $6 / 133$ & & $1.07[0.40,2.84]$ \\
\hline Subtotal (95\% CI) & 271 & 133 & > & $1.07[0.40,2.84]$ \\
\hline \multicolumn{5}{|c|}{ Total events: I3 (Formoterol/ICS), 6 (Salmeterol/Fluticasone) } \\
\hline \multicolumn{5}{|c|}{ Heterogeneity: not applicable } \\
\hline \multicolumn{5}{|c|}{ Test for overall effect: $Z=0.13(P=0.90)$} \\
\hline \multicolumn{5}{|c|}{4 Formoterol/fluticasone vs salmeterol/fluticasone } \\
\hline Bodzenta-Lukaszyk 2011 & $0 / 101$ & $1 / 101$ & & $0.14[0.00,6.82]$ \\
\hline Subtotal (95\% CI) & 101 & 101 & & $0.14[0.00,6.82]$ \\
\hline \multicolumn{5}{|c|}{ Total events: 0 (Formoterol//CS), I (Salmeterol/Fluticasone) } \\
\hline \multicolumn{5}{|c|}{ Heterogeneity: not applicable } \\
\hline \multicolumn{5}{|c|}{ Test for overall effect: $Z=1.00(P=0.32)$} \\
\hline Test for subgroup differences & $4, d f=2(P=0.57$ & & & \\
\hline
\end{tabular}

Regular treatment with formoterol and an inhaled corticosteroid versus regular treatment with salmeterol and an inhaled corticosteroid $4 \mathrm{I}$ for chronic asthma: serious adverse events (Review)

Copyright ( 201 I The Cochrane Collaboration. Published by John Wiley \& Sons, Ltd. 
Analysis I.3. Comparison I Fixed-dose formoterol/ICS versus salmeterol/fluticasone, Outcome 3 Asthma related non-fatal serious adverse events.

Review: Regular treatment with formoterol and an inhaled corticosteroid versus regular treatment with salmeterol and an inhaled corticosteroid for chronic asthma: serious adverse events

Comparison: I Fixed-dose formoterol/ICS versus salmeterol/fluticasone

Outcome: 3 Asthma related non-fatal serious adverse events

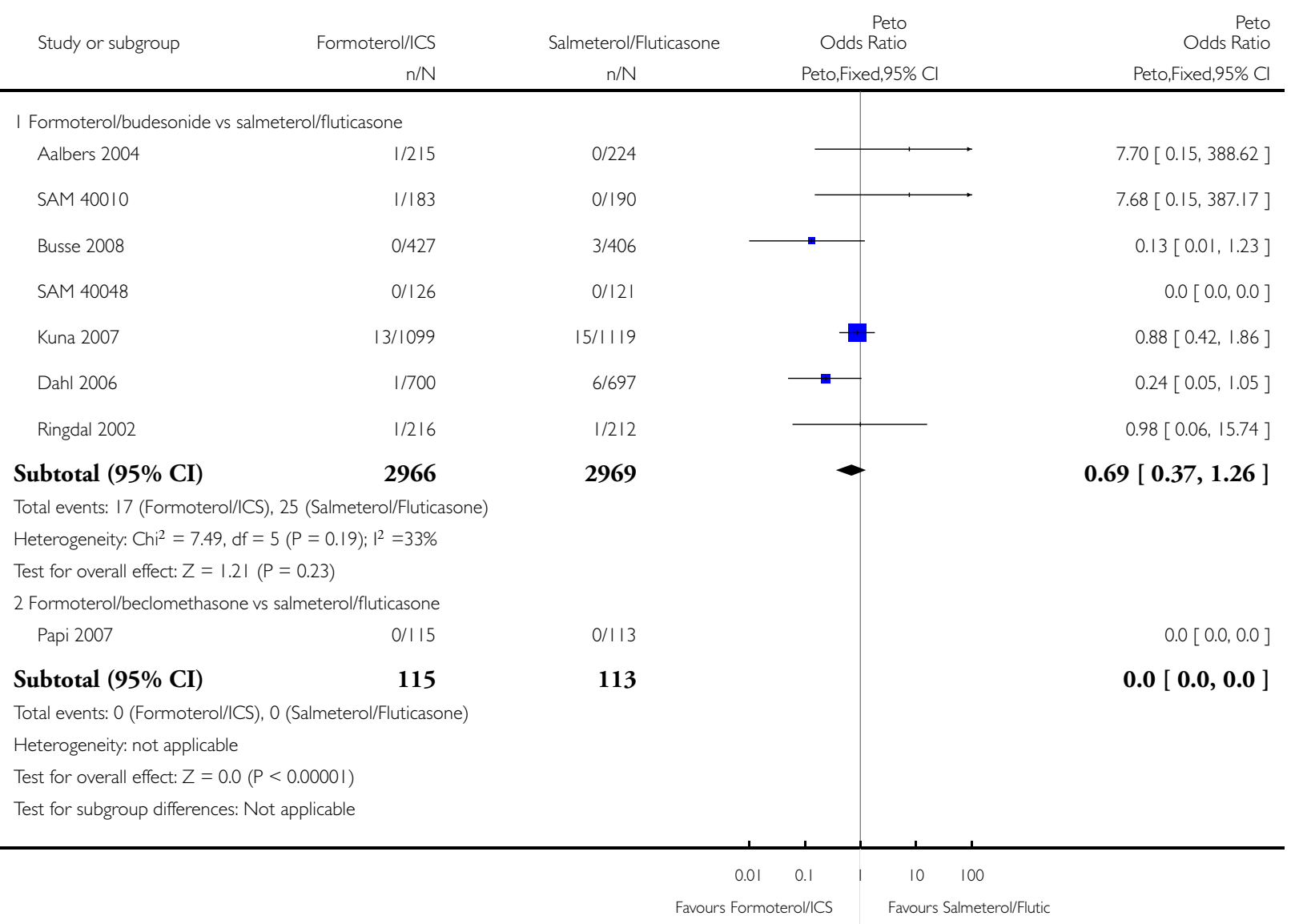

Regular treatment with formoterol and an inhaled corticosteroid versus regular treatment with salmeterol and an inhaled corticosteroid 42 for chronic asthma: serious adverse events (Review) 


\section{Analysis I.4. Comparison I Fixed-dose formoterol/ICS versus salmeterol/fluticasone, Outcome 4 All-cause mortality (risk difference).}

Review: Regular treatment with formoterol and an inhaled corticosteroid versus regular treatment with salmeterol and an inhaled corticosteroid for chronic asthma: serious adverse events

Comparison: I Fixed-dose formoterol/ICS versus salmeterol/fluticasone

Outcome: 4 All-cause mortality (risk difference)

\begin{tabular}{|c|c|c|c|c|c|}
\hline \multirow[t]{2}{*}{ Study or subgroup } & \multirow{2}{*}{$\begin{array}{r}\text { Formoterol//CS } \\
\mathrm{n} / \mathrm{N}\end{array}$} & \multirow{2}{*}{$\begin{array}{l}\text { Salmeterol/Fluticasone } \\
\mathrm{n} / \mathrm{N}\end{array}$} & \multirow{2}{*}{$\begin{array}{c}\text { Risk } \\
\text { Difference } \\
\text { M-H,Fixed,95\% Cl }\end{array}$} & \multirow[t]{2}{*}{ Weight } & $\begin{array}{r}\text { Risk } \\
\text { Difference }\end{array}$ \\
\hline & & & & & M-H,Fixed,95\% Cl \\
\hline \multicolumn{6}{|c|}{ | Formoterol/budesonide vs salmeterol/fluticasone } \\
\hline Aalbers 2004 & $0 / 215$ & $0 / 224$ & $\rightarrow$ & $7.4 \%$ & $0.0[-0.01,0.01]$ \\
\hline Busse 2008 & $0 / 427$ & 0/406 & 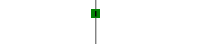 & $14.0 \%$ & $0.0[0.00,0.00]$ \\
\hline Dahl 2006 & $0 / 700$ & $0 / 697$ & 10 & $23.5 \%$ & $0.0[0.00,0.00]$ \\
\hline Kuna 2007 & 0/1099 & $1 / 1119$ & 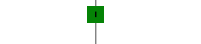 & $37.4 \%$ & $0.00[0.00,0.00]$ \\
\hline Ringdal 2002 & $0 / 216$ & $0 / 212$ & 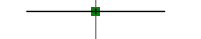 & $7.2 \%$ & $0.0[-0.01,0.01]$ \\
\hline SAM 40010 & $1 / 183$ & $0 / 190$ & & $6.3 \%$ & $0.01[-0.01,0.02]$ \\
\hline SAM 40048 & $0 / 126$ & $0 / 121$ & & $4.2 \%$ & $0.0[-0.02,0.02]$ \\
\hline Subtotal (95\% CI) & 2966 & 2969 & & $100.0 \%$ & $0.00[0.00,0.00]$ \\
\hline \multicolumn{6}{|c|}{ Total events: I (Formoterol//CS), I (Salmeterol/Fluticasone) } \\
\hline \multicolumn{6}{|c|}{ Heterogeneity: $\mathrm{Ch}^{2}=1.02, \mathrm{df}=6(P=0.98) ; \mathrm{I}^{2}=0.0 \%$} \\
\hline \multicolumn{6}{|c|}{ Test for overall effect: $Z=0.01(P=0.99)$} \\
\hline \multicolumn{6}{|c|}{2 Formoterol/beclomethasone vs salmeterol/fluticasone } \\
\hline Papi 2007 & $0 / 115$ & $0 / 113$ & & $100.0 \%$ & $0.0[-0.02,0.02]$ \\
\hline Subtotal $(95 \%$ CI $)$ & 115 & 113 & & $100.0 \%$ & $0.0[-0.02,0.02]$ \\
\hline \multicolumn{6}{|c|}{ Total events: 0 (Formoterol/ICS), 0 (Salmeterol/Fluticasone) } \\
\hline \multicolumn{6}{|c|}{ Heterogeneity: not applicable } \\
\hline \multicolumn{6}{|c|}{ Test for overall effect: $Z=0.0(P=1.0)$} \\
\hline \multicolumn{6}{|c|}{3 Formoterol/mometasone vs salmeterol/fluticasone } \\
\hline Maspero 2010 & $2 / 271$ & $0 / 133$ & & $100.0 \%$ & $0.01[-0.01,0.02]$ \\
\hline Subtotal (95\% CI) & 271 & 133 & & $100.0 \%$ & $0.01[-0.01,0.02]$ \\
\hline \multicolumn{6}{|c|}{ Total events: 2 (Formoterol/ICS), 0 (Salmeterol/Fluticasone) } \\
\hline \multicolumn{6}{|c|}{ Heterogeneity: not applicable } \\
\hline \multicolumn{6}{|c|}{ Test for overall effect: $Z=0.94(P=0.35)$} \\
\hline \multicolumn{6}{|c|}{4 Formoterol/fluticasone vs salmeterol/fluticasone } \\
\hline Bodzenta-Lukaszyk 201 I & $1 / 101$ & $0 / 101$ & & $100.0 \%$ & $0.01[-0.02,0.04]$ \\
\hline Subtotal (95\% CI) & 101 & 101 & & $100.0 \%$ & $0.01[-0.02,0.04]$ \\
\hline \multicolumn{6}{|c|}{ Total events: I (Formoterol//CS), 0 (Salmeterol/Fluticasone) } \\
\hline \multicolumn{6}{|c|}{ Heterogeneity: not applicable } \\
\hline \multicolumn{6}{|c|}{ Test for overall effect: $Z=0.72(P=0.47)$} \\
\hline \multicolumn{6}{|c|}{ Test for subgroup differences: Chi $^{2}=1.37, d f=3(P=0.71),\left.\right|^{2}=0.0 \%$} \\
\hline
\end{tabular}

Regular treatment with formoterol and an inhaled corticosteroid versus regular treatment with salmeterol and an inhaled corticosteroid 43 for chronic asthma: serious adverse events (Review)

Copyright (C) 201 I The Cochrane Collaboration. Published by John Wiley \& Sons, Ltd. 


\section{Analysis I.5. Comparison I Fixed-dose formoterol/ICS versus salmeterol/fluticasone, Outcome 5 All-cause non-fatal serious adverse events (risk difference).}

Review: Regular treatment with formoterol and an inhaled corticosteroid versus regular treatment with salmeterol and an inhaled corticosteroid for chronic asthma: serious adverse events

Comparison: I Fixed-dose formoterol//CS versus salmeterol/fluticasone

Outcome: 5 All-cause non-fatal serious adverse events (risk difference)

\begin{tabular}{|c|c|c|c|c|c|}
\hline \multirow[t]{2}{*}{ Study or subgroup } & \multirow{2}{*}{$\begin{array}{r}\text { Formoterol/ICS } \\
\mathrm{n} / \mathrm{N}\end{array}$} & \multirow{2}{*}{$\begin{array}{l}\text { Salmeterol/Fluticasone } \\
n / N\end{array}$} & \multirow{2}{*}{$\begin{array}{c}\text { Risk } \\
\text { Difference } \\
\text { M-H,Fixed,95\% Cl }\end{array}$} & \multirow[t]{2}{*}{ Weight } & \multirow{2}{*}{$\begin{array}{r}\text { Risk } \\
\text { Difference } \\
\text { M-H,Fixed,95\% Cl }\end{array}$} \\
\hline & & & & & \\
\hline \multicolumn{6}{|c|}{ | Formoterol/budesonide vs salmeterol/fluticasone } \\
\hline Aalbers 2004 & $11 / 215$ & $5 / 224$ & & $7.4 \%$ & $0.03[-0.01,0.06]$ \\
\hline Busse 2008 & $10 / 427$ & 9/406 & & $14.0 \%$ & $0.00[-0.02,0.02]$ \\
\hline Dahl 2006 & $11 / 700$ & $20 / 697$ & 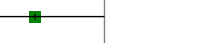 & $23.5 \%$ & $-0.01[-0.03,0.00]$ \\
\hline Kuna 2007 & $39 / 1099$ & $31 / 1119$ & + & $37.4 \%$ & $0.01[-0.01,0.02]$ \\
\hline Ringdal 2002 & $3 / 216$ & $2 / 212$ & & $7.2 \%$ & $0.00[-0.02,0.02]$ \\
\hline SAM 40010 & $2 / 183$ & $0 / 190$ & & $6.3 \%$ & $0.01[-0.01,0.03]$ \\
\hline SAM 40048 & $1 / 126$ & $|/| 2 \mid$ & & $4.2 \%$ & $0.00[-0.02,0.02]$ \\
\hline Subtotal (95\% CI) & 2966 & 2969 & 一 & $100.0 \%$ & $0.00[0.00,0.01]$ \\
\hline \multicolumn{6}{|c|}{ Total events: 77 (Formoterol/ICS), 68 (Salmeterol/Fluticasone) } \\
\hline \multicolumn{6}{|c|}{ Heterogeneity: $\mathrm{Chi}^{2}=7.46, \mathrm{df}=6(P=0.28) ; \mathrm{I}^{2}=20 \%$} \\
\hline \multicolumn{6}{|c|}{ Test for overall effect: $Z=0.79(P=0.43)$} \\
\hline \multicolumn{6}{|c|}{2 Formoterol/beclomethasone vs salmeterol/fluticasone } \\
\hline Papi 2007 & $0 / 115$ & $0 / 113$ & & $100.0 \%$ & $0.0[-0.02,0.02]$ \\
\hline Subtotal (95\% CI) & 115 & 113 & & $100.0 \%$ & $0.0[-0.02,0.02]$ \\
\hline \multicolumn{6}{|c|}{ Total events: 0 (Formoterol/ICS), 0 (Salmeterol/Fluticasone) } \\
\hline \multicolumn{6}{|c|}{ Heterogeneity: not applicable } \\
\hline \multicolumn{6}{|c|}{ Test for overall effect: $Z=0.0(P=1.0)$} \\
\hline \multicolumn{6}{|c|}{3 Formoterol/mometasone vs salmeterol/fluticasone } \\
\hline Maspero 2010 & $13 / 27 \mid$ & $6 / 133$ & & $100.0 \%$ & $0.00[-0.04,0.05]$ \\
\hline Subtotal (95\% CI) & 271 & 133 & & $100.0 \%$ & $0.00[-0.04,0.05]$ \\
\hline \multicolumn{6}{|c|}{ Total events: I3 (Formoterol/ICS), 6 (Salmeterol/Fluticasone) } \\
\hline \multicolumn{6}{|l|}{ Heterogeneity: not applicable } \\
\hline \multicolumn{6}{|c|}{ Test for overall effect: $Z=0.13(P=0.90)$} \\
\hline \multicolumn{6}{|c|}{4 Formoterol/fluticasone vs salmeterol/fluticasone } \\
\hline Bodzenta-Lukaszyk 201। & $0 / 101$ & $1 / 10 \mid$ & & $100.0 \%$ & $-0.01[-0.04,0.02]$ \\
\hline Subtotal (95\% CI) & 101 & 101 & & $100.0 \%$ & $-0.01[-0.04,0.02]$ \\
\hline \multicolumn{6}{|c|}{ Total events: 0 (Formoterol/ICS), I (Salmeterol/Fluticasone) } \\
\hline & & -0.02 & 0.01 & 0.02 & \\
\hline & & Favours Formo & Favours S & Salmetero//Flutic & \\
\hline
\end{tabular}

Regular treatment with formoterol and an inhaled corticosteroid versus regular treatment with salmeterol and an inhaled corticosteroid 


\begin{tabular}{|c|c|c|c|c|c|}
\hline \multirow[t]{2}{*}{ Study or subgroup } & Formoterol//CS & Salmeterol/Fluticasone & $\begin{array}{r}\text { Risk } \\
\text { Difference }\end{array}$ & Weight & $\begin{array}{r}\text { Risk } \\
\text { Difference }\end{array}$ \\
\hline & $n / N$ & $n / N$ & M-H,Fixed,95\% Cl & & M-H,Fixed, $95 \% \mathrm{Cl}$ \\
\hline
\end{tabular}

$\begin{array}{ccccc}-0.02 & -0.01 & 0 & 0.01 & 0.02 \\ & \text { Favours Formoterol//CS } & \text { Favours Salmeterol/Flutic }\end{array}$

\section{Analysis I.6. Comparison I Fixed-dose formoterol/ICS versus salmeterol/fluticasone, Outcome 6 Asthma- related non-fatal serious adverse events (risk difference).}

Review: Regular treatment with formoterol and an inhaled corticosteroid versus regular treatment with salmeterol and an inhaled corticosteroid for chronic asthma: serious adverse events

Comparison: I Fixed-dose formoterol//CS versus salmeterol/fluticasone

Outcome: 6 Asthma-related non-fatal serious adverse events (risk difference)

\begin{tabular}{|c|c|c|c|c|c|}
\hline \multirow[t]{2}{*}{ Study or subgroup } & \multirow{2}{*}{$\begin{array}{r}\text { Formoterol//CS } \\
\mathrm{n} / \mathrm{N} \\
\end{array}$} & \multirow{2}{*}{$\begin{array}{c}\text { Salmeterol/Fluticasone } \\
n / N\end{array}$} & $\begin{array}{r}\text { Risk } \\
\text { Difference }\end{array}$ & \multirow[t]{2}{*}{ Weight } & $\begin{array}{r}\text { Risk } \\
\text { Difference }\end{array}$ \\
\hline & & & M-H,Fixed,95\% Cl & & M-H,Fixed,95\% Cl \\
\hline \multicolumn{6}{|c|}{ I Formoterol/budesonide vs salmeterol/fluticasone } \\
\hline Aalbers 2004 & $1 / 215$ & $0 / 224$ & $\rightarrow$ & $7.4 \%$ & $0.00[-0.01,0.02]$ \\
\hline Busse 2008 & $0 / 427$ & $3 / 406$ & $\rightarrow$ & $14.0 \%$ & $-0.01[-0.02,0.00]$ \\
\hline Dahl 2006 & $1 / 700$ & $6 / 697$ & 『- & $23.5 \%$ & $-0.01[-0.01,0.00]$ \\
\hline Kuna 2007 & $13 / 1099$ & $15 / 1119$ & $\rightarrow$ & $37.4 \%$ & $0.00[-0.01,0.01]$ \\
\hline Ringdal 2002 & $1 / 216$ & $1 / 212$ & $\rightarrow$ & $7.2 \%$ & $0.00[-0.01,0.01]$ \\
\hline SAM 40010 & $1 / / 83$ & $0 / 190$ & - & $6.3 \%$ & $0.01[-0.01,0.02]$ \\
\hline SAM 40048 & $0 / 126$ & $0 / 121$ & & $4.2 \%$ & $0.0[-0.02,0.02]$ \\
\hline Subtotal $(95 \%$ CI $)$ & 2966 & 2969 & 7 & $100.0 \%$ & $0.00[-0.01,0.00]$ \\
\hline \multicolumn{6}{|c|}{ Total events: 17 (Formoterol//CS), 25 (Salmeterol/Fluticasone) } \\
\hline \multicolumn{6}{|c|}{ Heterogeneity: $\mathrm{Ch}^{2}=5.12, \mathrm{df}=6(P=0.53) ; 1^{2}=0.0 \%$} \\
\hline \multicolumn{6}{|c|}{ Test for overall effect: $Z=1.16(P=0.25)$} \\
\hline \multicolumn{6}{|c|}{2 Formoterol/beclomethasone vs salmeterol/fluticasone } \\
\hline Papi 2007 & $0 / 115$ & $0 / 113$ & & $100.0 \%$ & $0.0[-0.02,0.02]$ \\
\hline Subtotal (95\% CI) & 115 & 113 & $=$ & $100.0 \%$ & $0.0[-0.02,0.02]$ \\
\hline
\end{tabular}




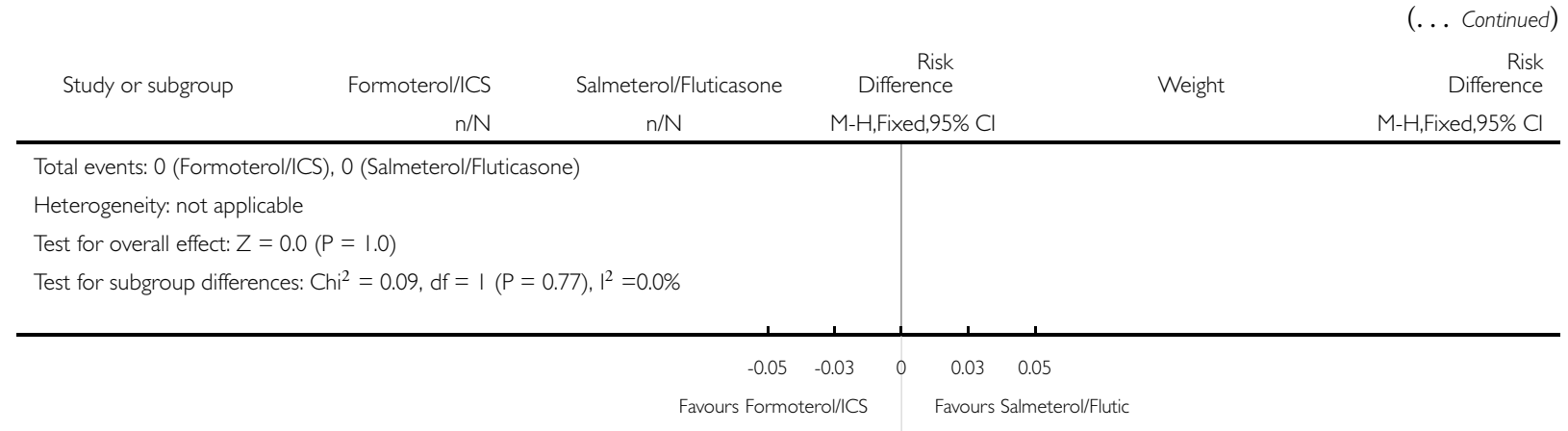

\section{A D D ITIONAL TABLES}

Table 1. Details of the dose and type of medication used

\begin{tabular}{|c|c|c|c|c|c|c|}
\hline Study ID & $\begin{array}{l}\text { Formoterol de- } \\
\text { vice }\end{array}$ & $\begin{array}{l}\text { Formoterol } \\
\text { dose }\end{array}$ & $\begin{array}{l}\text { ICS type and } \\
\text { dose }\end{array}$ & $\begin{array}{l}\text { Salmeterol de- } \\
\text { vice }\end{array}$ & Salmeterol dose & $\begin{array}{l}\text { ICS type and } \\
\text { dose }\end{array}$ \\
\hline Aalbers 2004 & DPI & $12 \mu \mathrm{g} \mathrm{bd}$ & $\begin{array}{l}\text { Budesonide } 400 \\
\mu \mathrm{g} \text { bd }\end{array}$ & DPI & $50 \mu \mathrm{g} \mathrm{bd}$ & $\begin{array}{l}\text { Fluticasone } 250 \\
\mu \mathrm{g} \text { bd }\end{array}$ \\
\hline $\begin{array}{l}\text { Bodzenta- } \\
\text { Lukaszyk } 2011\end{array}$ & $\begin{array}{l}\text { HFA pMDI } \\
\text { with AeroCham- } \\
\text { ber }\end{array}$ & $10 \mu \mathrm{g} \mathrm{bd}$ & $\begin{array}{l}\text { Fluticasone } 100 \\
\mu \mathrm{g} \text { or } 250 \mu \mathrm{g} \text { bd }\end{array}$ & $\begin{array}{l}\text { HFA pMDI } \\
\text { with AeroCham- } \\
\text { ber }\end{array}$ & $50 \mu \mathrm{g} \mathrm{bd}$ & $\begin{array}{l}\text { Fluticasone } 100 \\
\mu \mathrm{g} \text { or } 250 \mu \mathrm{g} \text { bd }\end{array}$ \\
\hline Busse 2008 & pMDI & $12 \mu \mathrm{g} \mathrm{bd}$ & $\begin{array}{l}\text { Budesonide } 400 \\
\mu \mathrm{g} \text { bd }\end{array}$ & DPI & $50 \mu \mathrm{g}$ bd & $\begin{array}{l}\text { Fluticasone } 250 \\
\mu \mathrm{g} \text { bd }\end{array}$ \\
\hline Dahl 2006 & DPI & $12 \mu \mathrm{g} \mathrm{bd}$ & $\begin{array}{l}\text { Budesonide } 400 \\
\mu \mathrm{g} \text { bd }\end{array}$ & DPI & $50 \mu \mathrm{g}$ bd & $\begin{array}{l}\text { Fluticasone } 250 \\
\mu \mathrm{g} \text { bd }\end{array}$ \\
\hline Kuna 2007 & DPI & $12 \mu \mathrm{g} \mathrm{bd}$ & $\begin{array}{l}\text { Budesonide } 400 \\
\mu \mathrm{g} \text { bd }\end{array}$ & pMDI & $50 \mu \mathrm{g}$ bd & $\begin{array}{l}\text { Fluticasone } 250 \\
\mu \mathrm{g} \text { bd }\end{array}$ \\
\hline Maspero 2010 & pMDI & $10 \mu \mathrm{g} \mathrm{bd}$ & $\begin{array}{l}\text { Mometasone } \\
200 \mu \mathrm{g} \text { or } 400 \mu \mathrm{g} \\
\text { bd }\end{array}$ & pMDI & $50 \mu \mathrm{g} \mathrm{bd}$ & $\begin{array}{l}\text { Fluticasone } 250 \\
\mu \mathrm{g} \text { or } 500 \mu \mathrm{g} \text { bd }\end{array}$ \\
\hline Papi 2007 & pMDI & $12 \mu \mathrm{g} \mathrm{bd}$ & $\begin{array}{l}\text { Beclometha- } \\
\text { sone extra fine } \\
200 \mu \mathrm{g} \text { bd }\end{array}$ & pMDI & $50 \mu \mathrm{g} \mathrm{bd}$ & $\begin{array}{l}\text { Fluticasone } 250 \\
\mu \mathrm{g} \text { bd }\end{array}$ \\
\hline Ringdal 2002 & $\begin{array}{l}\text { DPI two separate } \\
\text { inhalers }\end{array}$ & $12 \mu \mathrm{g} \mathrm{bd}$ & $\begin{array}{l}\text { Budesonide } 800 \\
\boldsymbol{\mu g} \text { bd }\end{array}$ & DPI & $50 \mu \mathrm{g} \mathrm{bd}$ & $\begin{array}{l}\text { Fluticasone } 250 \\
\mu \mathrm{g} \text { bd }\end{array}$ \\
\hline SAM 40010 & DPI & $6 \mu \mathrm{g} b d$ & $\begin{array}{l}\text { Budesonide } 200 \\
\boldsymbol{\mu g} \text { bd }\end{array}$ & DPI & $50 \mu \mathrm{g} \mathrm{bd}$ & $\begin{array}{l}\text { Fluticasone } 100 \\
\boldsymbol{\mu g} \text { bd }\end{array}$ \\
\hline
\end{tabular}

Regular treatment with formoterol and an inhaled corticosteroid versus regular treatment with salmeterol and an inhaled corticosteroid 46 
Table 1. Details of the dose and type of medication used (Continued)

\begin{tabular}{|c|c|c|c|c|c|c|}
\hline SAM 40048 & DPI & $6 \mu \mathrm{g} b d$ & $\begin{array}{l}\text { Budesonide } 200 \\
\boldsymbol{\mu g} \text { bd }\end{array}$ & DPI & $50 \mu \mathrm{g} \mathrm{bd}$ & $\begin{array}{l}\text { Fluticasone } 250 \\
\mu \mathrm{g} \text { bd }\end{array}$ \\
\hline
\end{tabular}

Doses shown are ex-actuator rather than delivered doses.

bd: twice a day

DPI: dry powder inhaler

ICS: inhaled corticosteroid

HFA: hydrofluoroalkane

pMDI: pressurised metered dose inhaler

Table 2. Details of the study participants, location and sponsors

\begin{tabular}{|c|c|c|c|c|c|}
\hline Study ID & $\begin{array}{l}\text { Number } \\
\text { randomised }\end{array}$ & Duration & Age & Location & Sponsors \\
\hline Aalbers 2004 & 658 & $\begin{array}{l}26 \text { weeks (open ex- } \\
\text { tension) }\end{array}$ & $12+$ & Europe & AstraZeneca \\
\hline $\begin{array}{l}\text { Bodzenta-Lukaszyk } \\
2011\end{array}$ & 202 & 12 weeks & $18+$ & Europe & Mundipharma \\
\hline Busse 2008 & 1225 & 30 weeks & $12+$ & USA & AstraZeneca \\
\hline Dahl 2006 & 1397 & 24 weeks & $18+$ & Europe & GlaxoSmithKline \\
\hline Kuna 2007 & 3335 & 24 weeks & $12+$ & Multinational & AstraZeneca \\
\hline Maspero 2010 & 404 & 52 weeks & $12+$ & South America & Merck \\
\hline Papi 2007 & 228 & 12 weeks & $18+$ & Europe & Chiesi \\
\hline Ringdal 2002 & 428 & 12 weeks & $16+$ & Europe & GlaxoSmithKline \\
\hline SAM 40010 & 373 & 12 weeks & $12+$ & Europe & GlaxoSmithKline \\
\hline SAM 40048 & 248 & 12 weeks & $18+$ & Germany & GlaxoSmithKline \\
\hline
\end{tabular}




\section{A P P E N D I C E S}

Appendix I. Sources and search methods for the Cochrane Airways Group Specialised Register (CAGR)

Electronic searches: core databases

\begin{tabular}{ll}
\hline Database & Frequency of search \\
\hline MEDLINE (Ovid) & Weekly \\
\hline EMBASE (Ovid) & Weekly \\
\hline CENTRAL (T he Cochrane Library) & Quarterly \\
\hline PSYCINFO (Ovid) & Monthly \\
\hline CINAHL (EBSCO) & Monthly \\
\hline AMED (EBSCO) & Monthly
\end{tabular}

Handsearches: core respiratory conference abstracts

\begin{tabular}{l|l}
\hline Conference & Years searched \\
\hline American Academy of Allergy, Asthma and Immunology (AAAAI) & 2001 onwards \\
\hline American Thoracic Society (ATS) & 2001 onwards \\
\hline Asia Pacific Society of Respirology (APSR) & 2004 onwards \\
\hline British Thoracic Society Winter Meeting (BTS) & 2000 onwards \\
\hline Chest Meeting & 2003 onwards \\
\hline European Respiratory Society (ERS) & $1992,1994,2000$ onwards \\
\hline International Primary Care Respiratory Group Congress (IPCRG) & 2002 onwards \\
\hline Thoracic Society of Australia and New Zealand (TSANZ) & 1999 onwards \\
\hline
\end{tabular}

Regular treatment with formoterol and an inhaled corticosteroid versus regular treatment with salmeterol and an inhaled corticosteroid 


\section{MEDLINE search strategy used to identify trials for the CAGR}

\section{Asthma search}

1. exp Asthma/

2. asthma\$.mp.

3. (antiasthma $\$$ or anti-asthma $\$$ ).mp.

4. Respiratory Sounds/

5. wheez\$.mp.

6. Bronchial Spasm/

7. bronchospas $\$ . m p$.

8. (bronch $\$$ adj3 spasm $\$$ ).mp.

9. bronchoconstrict $\$ . \mathrm{mp}$.

10. exp Bronchoconstriction/

11. (bronch\$ adj3 constrict\$).mp.

12. Bronchial Hyperreactivity/

13. Respiratory Hypersensitivity/

14. ((bronchial\$ or respiratory or airway $\$$ or lung $\$$ ) adj3 (hypersensitiv\$ or hyperreactiv $\$$ or allerg $\$$ or insufficiency)).mp.

15. ((dust or mite\$) adj3 (allerg\$ or hypersensitiv\$)).mp.

16. or/1-15

\section{Filter to identify RCTs}

1. exp "clinical trial [publication type]"/

2. (randomised or randomised).ab,ti.

3. placebo.ab,ti.

4. dt.fs.

5. randomly.ab,ti.

6. trial.ab,ti.

7. groups.ab,ti.

8. or/1-7

9. Animals/

10. Humans/

11. 9 not (9 and 10)

12. 8 not 11

The MEDLINE strategy and RCT filter are adapted to identify trials in other electronic databases.

\section{WHAT'S NEW}

Last assessed as up-to-date: 17 August 2011.

\begin{tabular}{|c|c|c|}
\hline Date & Event & Description \\
\hline 17 August 2011 & New search has been performed & $\begin{array}{l}\text { New search in August } 2011 \text { identified one new included study on } 202 \\
\text { adults comparing formoterol and fluticasone with salmeterol and fluticasone } \\
\text { (Bodzenta-Lukaszyk 2011), and one new study on } 404 \text { adults comparing for- } \\
\text { moterol and mometasone with salmeterol and fluticasone (Maspero 2010). }\end{array}$ \\
\hline
\end{tabular}

Regular treatment with formoterol and an inhaled corticosteroid versus regular treatment with salmeterol and an inhaled corticosteroid 


\section{H I S T O R Y}

Protocol first published: Issue 2, 2009

Review first published: Issue 1, 2010

\begin{tabular}{l|l|l}
\hline Date & Event & Description \\
\hline 15 August 2011 & Amended & Typological error in abstract corrected (dose of formoterol changed from $50 \mu \mathrm{g}$ to $12 \mu \mathrm{g})$ \\
\hline
\end{tabular}

\section{CONTRIBUTIONS OFAUTHORS}

CJC: conception of the idea and co-writing of protocol, data extraction, analysis and writing the review and update.

TL: data extraction and co-writing of the review and update.

\section{DECLARATIONS OF INTEREST}

None known.

\section{SOURCES OF SUPPORT}

\section{Internal sources}

- No sources of support supplied

\section{External sources}

- NHS R\&D, UK.

National Institute of Health Research: Programme Grant

\section{DIFFERENCES BETWEEN PROTOCOLAND REVIEW}

No subgroup analysis was possible on the basis of age or dose-equivalence of inhaled corticosteroids.

\section{N DEX TERMS}




\section{Medical Subject Headings (MeSH)}

Administration, Inhalation; Albuterol [administration \& dosage; adverse effects; *analogs \& derivatives]; Androstadienes [administration \& dosage; adverse effects]; Anti-Asthmatic Agents [administration \& dosage; *adverse effects]; Asthma [*drug therapy; mortality]; Budesonide [administration \& dosage; adverse effects]; Drug Therapy, Combination [adverse effects]; Ethanolamines [administration \& dosage; *adverse effects]; Glucocorticoids [administration \& dosage; *adverse effects]; Randomized Controlled Trials as Topic

\section{MeSH check words}

Adolescent; Adult; Humans

Regular treatment with formoterol and an inhaled corticosteroid versus regular treatment with salmeterol and an inhaled corticosteroid 5 for chronic asthma: serious adverse events (Review)

Copyright ( 201 I The Cochrane Collaboration. Published by John Wiley \& Sons, Ltd. 